\title{
EXAFS および表面 EXAFS における放射光の利用
}

\author{
大柳 宏之* ・太田 俊明**
}

（昭和57年 9 月 6 日 受理）

Application of Synchrotron Radiation to EXAFS and SEXAFS

Hiroyuki ŌYANAGI* and Toshiaki ŌTA**

(*Electrotechnical Laboratory, 1-1-4 Umezono, Sakura-mura, Niihari-gun, Ibaraki)

(**National Laboratory for High Energy Physics, 1-1 Uehara, Oho-machi,

Tsukuba-gun, Ibaraki)

(Received September 6, 1982)

\section{1.はじめに}

物質のミクロな構造を調べることは, 物質の研究の中 で, 最も基本的かつ重要なものである，これまでにもい くつかの方法が開発されているが，その代表的なものは X線回折や中性子線回折のよ $5 に$ 原子の周期的な構造に よる回折効果を利用したものである.

一方，X線の吸収スペクトルに掠いて，その広い吸収 域に微細な振動構造が現われ，これが，物質の構造 と 何らかの関係があることが，既に 1930年 代に知られて いた ${ }^{1)}$. しかし,この現象, EXAFS (Extended Xray Absorption Fine Structure) は単なる物理現象として放 置されたままになっていた. ところが，1970年代に入っ て, Sayers, Stern, Lytle 達が, EXAFS のフーリェ変 換が中心原子のまわりの動径分布を与えることを示 し2，新たに，構造解析の手段として注目されるように なった. 更に, 1975年頃より光源として, 強力な白色光 源である放射光が利用されるよらになり，測定時間を大 幅に短縮化することができた. このよらに，解析法の開 発と, 新しい強力光源の利用は, EXAFS の飛躍的な発 展へと導いた。 この EXAFS の特徽は, (1)近距離秩序 に基づいているため, 長距離秩序を有しない液体や非晶 質固体に適用することができる. (2)単結晶を必要としな いため, 複雑な生体物質に適用できる, (3) X線回折に比 べて極めて希薄な濃度の原子でも有効である, 等があげ られよう。

$*$ 電子技術総合研究所 (茨城県新治郡桜村)

** 高エネルギー物理学研究所 (茨城県筑波郡大穂町)
これまで，EXAFS に関しては多くの総説や成書が出 されているが, ここでは, EXAFS の解析法, 実験法に 重点を置き，できるだけ新しい情報を紹介するよう努力 したつもりである. 特に放射光を光源とした実験に中心 をおいて詳しく説明した，実験室系および。電子線を用 いた EXAFS 等は別の総説・論文を参考にされたい. これらのリストを最後にまとめた.

\section{FXAFS の理論}

\subsection{EXAFS の基本公式}

一般にX線の吸収スペクトルは内殼電子の結合エネル ギーに対応した位置で急激に立上がり，それから次第に 減少する形をとる．X線吸収は内殼準位の励起と密接な 関係があり，その確率はいわゆる Golden rule によって 次式で表わされる.

$$
\sigma=\frac{2 \pi}{\hbar} \sum\left|\left\langle\psi_{f}|e \cdot \boldsymbol{\varepsilon} \cdot \boldsymbol{r}| \psi_{i}\right\rangle\right|^{2} \delta\left(E_{i}+\hbar \omega-E_{f}\right)
$$

ここで, $\varepsilon$ は電場の偏向ベクトル, $E_{i}, E_{f}$ は始状態, 終状態のエネルギーである，今，多原子分子や固体のよ らな系を考えると，内殼励起によってとびだした電子は 周囲の原子によって散乱を受ける。このとき終状態の波 動関数は

$$
\left|\psi_{f}\right\rangle=\left|\psi_{\text {out }}\right\rangle+\left|\psi_{\text {scat }}\right\rangle
$$

そして，外にとびだす電子の波動関数 $\psi_{\text {out }}$ は次式の形 に表わされる.

$$
\psi_{\text {out }}=h_{e}{ }^{+}(k r) Y_{e m}(\theta, \phi) \exp \left\{2 i \delta_{e}\right\}
$$

ここで, $h_{l}^{+}(k r)$ は球面ハンケル関数, $Y_{l m}(\theta, \phi)$ は球 


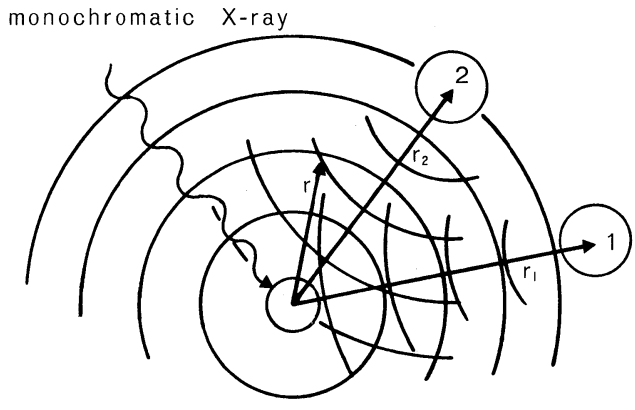

図 1 EXAFS の原理

面調和関数， $\delta_{l}$ は外にとびだすときの ポテンシャルの 影響による位相シフトである。

散乱された電子の波動関数は Green 関数を用いると 次式のようになる

$$
\psi_{\text {scat }}=\sum_{i}\left(E-H_{0}\right)^{-1} T\left(\boldsymbol{r}_{i}\right) \psi_{\text {out }}\left(r_{i}\right)
$$

ここで, $\left(E-H_{0}\right)^{-1}$ は Green 関数, $T\left(\boldsymbol{r}_{i}\right)$ はいわゆ る $T$ 行列であり，これによって $\psi_{\text {out }}$ が $\boldsymbol{r}_{i}$ の位置にある 原子によって散乱を受けて $\boldsymbol{r}$ まで伝幡した後の 波動 関 数を表現する (図 1 参照).

周囲に散乱原子がなければ， $\left|\psi_{f}\right\rangle=\left|\psi_{\text {out }}\right\rangle$ だけであ り波数ベクトル $k$ の増加に伴って， $\sigma$ は単調減少する が， $\left|\psi_{\text {scat }}\right\rangle$ の $\sigma$ に対する寄与は $\mathrm{k}$ の大きさによって変 化する.

EXAFS はこの散乱効果を抽出したものであり，これ を表わすものとして $れ$ 次のように定義する。

$$
\chi(k)=\frac{\mu-\mu_{0}}{\mu_{0}}=\frac{\sigma-\sigma_{0}}{\sigma_{0}}
$$

ここで, $\mu$ は吸収係数, $\mu_{0}, \sigma_{0}$ は周囲に散乱原子が な い場合の值を示寸. 図 2 にニッケルはくの K吸収スペク トルを示す.

今，簡単のため，球対称な結晶系での $\mathrm{K}$ 殼の吸収を考 えると， $\chi(k)$ は次式のように表わされる.

$$
\begin{gathered}
\chi(k)=\sum A_{i}(k) \sin \left(2 k R_{i}+2 \delta_{i}{ }^{\prime}(k)\right) \\
A_{i}(k)=N_{i} / k R_{i}{ }^{2} \times F_{i}(k) \\
\quad \times \exp \left\{-2 \sigma_{i}{ }^{2} k^{2}\right\} \exp \left\{-2 R_{i} / \lambda_{i}(k)\right\} \\
k=\sqrt{2 m\left(E-E_{b}\right)} / \hbar
\end{gathered}
$$

ここで， $E$ は入射フォトンのエネルギー， $E_{b}$ は吸収 端の限界エネルギーである。 また $F_{i}(k)$ は距離 $R_{i}$ 離 れ た $i$ 番目の殼にある $N_{i}$ 個の原子による後方散乱の振 幅 である. $\exp \left\{-2 \sigma_{i}{ }^{2} k^{2}\right\}$ の項は原子の熱振動を考慮した Debye-Waller 因子, $\exp \left\{-2 R_{i} / \lambda_{i}(k)\right\}$ は電子が散乱さ れて帰ってくるまでの間に非弾性的な損失を受けコヒー レントでなくなる効果をとり入れたもので, $\lambda_{i}(k)$ は平

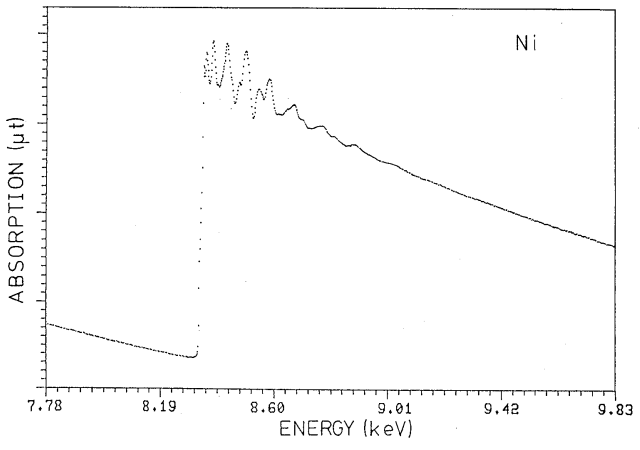

図 2 ニッケルはくのK吸収スペクトル

均自由行程である.

(1)式から(6)式を導き出すにあたって以下のような仮定 を用いた ${ }^{3 \sim 5)}$.

(i)漸近波の仮定— $k r$ が大きいところでは, $h^{+}(k r)$ $\approx \mathrm{e}^{i k r} / k r$ で近似できる. また, $\mathrm{K}$ 殼吸収であるから $l=$ $1, m=0$ として, $Y_{10}(\theta, \phi)=\cos \theta$ であるから

$$
\psi_{\text {out }}=\mathrm{e}^{i k r} / k r \times \cos \theta
$$

(ii)点散乱の仮定一一周囲の原子を点で近似し, 散乱の ポテンシャルを次式で表わす.

$$
V(r)=V_{0} \delta\left(r-r_{i}\right)
$$

そして, 散乱された電子の波動関数は

$$
\psi_{\text {scat }}(r)=V_{0} \sum\left(E-H_{0}\right)^{-1} \delta\left(r-r_{i}\right) \psi_{f}(r)
$$

(iii)一回散乱の仮定一一電子は隣接する原子に一回散乱 して外に飛びでると仮定する. 散乱が一回増える毎に $1 / k r$ だけ寄与が減少するので， $k$ の大きい領城では多重 散乱は無視できる。

(6)式のもつ意味を少し考察しておこう. 隣接原子間距 離が大きい程短い周期で振動する。 また，その振幅 $A_{\boldsymbol{i}}$ (k) は配位数 $N_{i}$ に比例しているため, 取り囲む原子の 数が多い程振幅が大きくなる．この様子を模式的に図 3 に示した ${ }^{7)}$. 振幅は $\exp \left\{-2 R_{i} / \lambda_{i}(h)\right\} / R_{i}{ }^{2}$ に比例してい るから，距離が大きくなれば， $\chi(k)$ に対する寄与は小さ くなる. 言い換えれば, 最隣接原子間距離が強調されて でてくる.一方，Debye-Waller 因子 ${\sigma_{i}}^{2}$ は温度が低くな る程小さくなるから，低温での実験では EXAFS シグナ ルが大きくなる.

(6)式において更に位相シフトに次の仮定を用いる.

(iv) 位相シフト $\delta^{\prime}(k)$ は $\mathrm{k} の 一$ 次関数で表わされる.

$$
\delta^{\prime}(k)=\alpha k+\delta_{0}
$$

この仮定の妥当性は後の詳細な理論計算 ${ }^{6)}$ からも裏付 けられた. この仮定を用いることによって， $\chi(k)$ のフー リエ変換は, $r=\left(R_{i}+{ }_{2}^{1} \alpha\right)$ で鋭いピークをもつことにな る. 


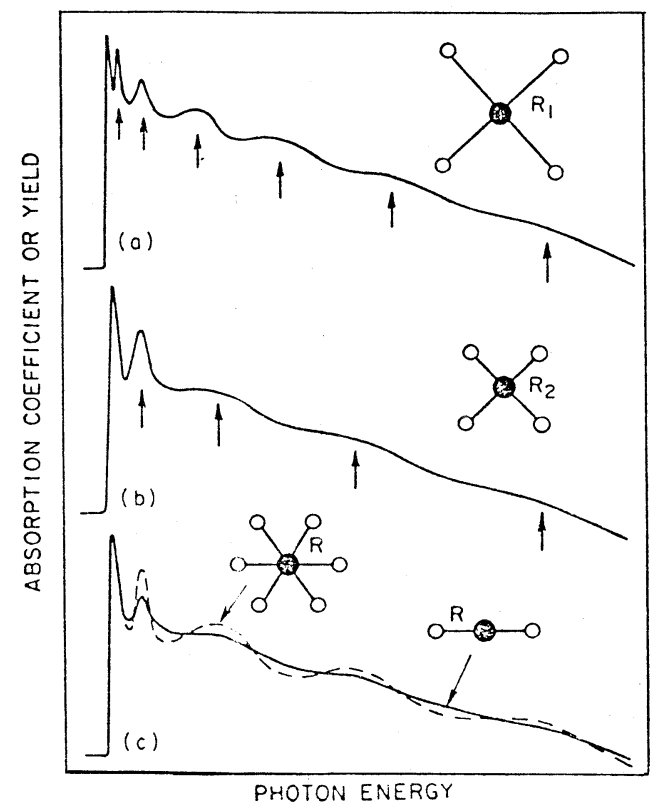

図 3 (a) 結合距離が長いと周期が短い

(b) 結合距離が短いと周期が長くなる

(c) 配位数が多くなると, 振幅が大きくなる

$F(r)=\frac{1}{2 \pi} \int_{0}^{\infty} \mathrm{d} k \mathrm{e}^{-2 i k} \chi(k)$

もし， $\alpha$ が中心原子のみに依存する量であるなら，一 つの標準結晶で $\alpha$ を決定したのち，これを未知試料に応 用して結合距離を求めることができよう.

上記のような Stern らによる理論とフーリェ変換を用 いる解析法は，その理論の簡明さの故に，これまで多く の物質の結合距離を求めることに利用されている.

\subsection{EXAFS 理論の諸問題}

Stern らの理論5) を更に厳密にするための努力が， Ashley と Doniash’ や, Lee と Pendry4) らによって払わ れてきた.

ここでは, 上記の簡単な理論の問題点をいくつかあげ るにとどめる.

(i) 位相シフトと後方散乱振幅の題額

(6)，(7)，(8)式からわかるように, EXAFS の振動 $\chi(k)$ を決めるいくつかのパラメータがある。それらは, 特に 高い相関がある $2 つ$ 組 $\{F(k), \sigma, \lambda, N\}$ と $\left\{\delta(k), E_{0}\right.$, $R\}$ に分けられる. 即ち, $N$ やを決めるには後方散乱振 幅 $F(k)$ を正確に知ることが必要であるし，Rを決めるに は位相シフト $\delta(k)$ を知らなければならない.これらはモ デル化合物から求めることもできるが，かなり正確な理 論計算が可能になった. 計算法は，原子と外にとびでた 電子からなる系を繰り返しで解く $\mathrm{HF}$ 法 ${ }^{4)}$ や，交換項を Slater の局在密度で表わす HFS 法3)が用いられている.

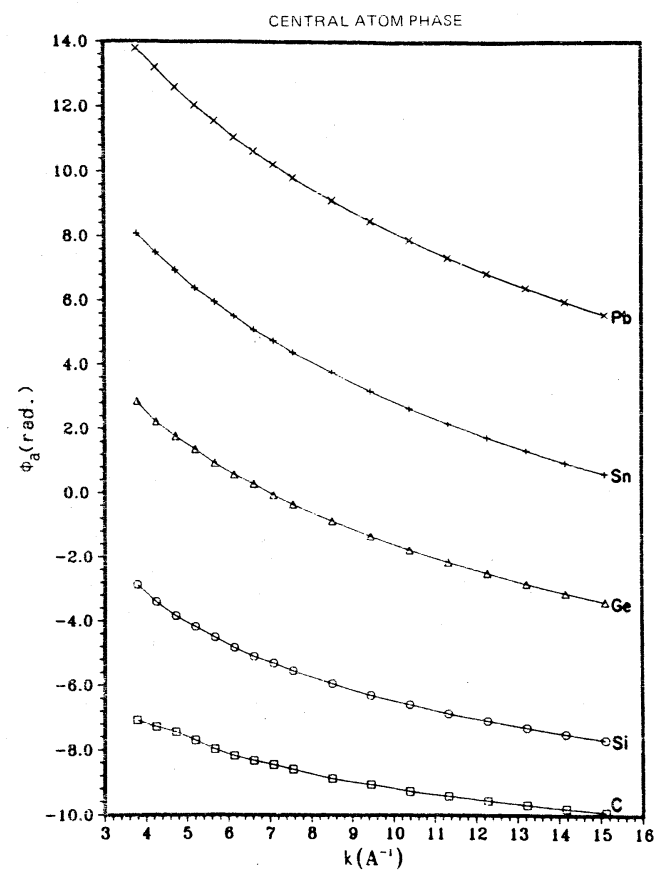

図 4 中心原子の位相シフトの計算值

低エネルギーでは HF 法が，高エネルギーでは HFS 法 が良い表現法であり，この両者を内挿する方法8 られている. 図 4 亿中心原子の位相シフトの計算例 6 を 示す.これらは前述のようにほぼ $k$ の一次に比例してい る.

一方, 後方散乱振幅の $k$ 依存性 ${ }^{7)}$ は図 5 に示したよう に原子番号 $Z$ に大きく依存している. 即ち, $C$ のような 軽原子は $k$ の小さいところでピークをもち単調減少する が，重原子になると内殼電子との共鳴によって中間の $k$ でピークを持つ。このことは EXAFS スペクトルを解 析する上で極めて興味深い，散乱原子が何であるか少な くとも原子番号の大きい原子かそうでないかは，その振 幅をみることによって推定できる.

(ii) 多重散乱の問題

(6)式では一回散乱の仮定を用いた. 一般に電子の可 動距離は非常に限られており，何回も散乱を受けてもと の原子に戻る確率は小さく, 振幅に対する寄与は無視で きる.しかし，例外的な場合もある．それは，直線的な 配列をしているような場合であり，介在する原子によっ て前方散乱が強められる．直線から $30^{\circ}$ 以上ずれるとこ の効果は急激に弱くなる. 有名な例は $\mathrm{Cu}$ の EXAFSで

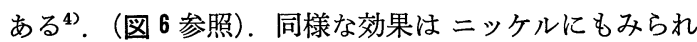
る. 第四殼は最隣接原子の殼の線上にあるために，その 振幅が強められている.

また, 吸収端近傍のエネルギーでは平均自由行程が長 


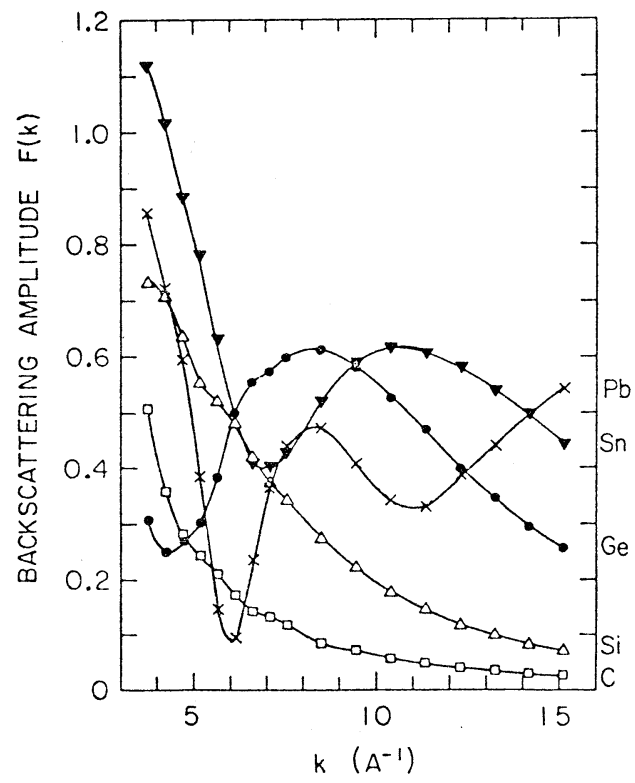

図 5 後方散乱振幅のエネルギー依存性

く, 多重散乱の効果が無視できない. 一般にこの領域は EXAFS の解析ではとり除いている。このような多重散 乱の効果は結合角と密接な関係があることは興味深い.

最近，多重散乱を考慮した理論によって結合角を求める 試みもなされている.

(iii) 格子振動の問題

Sayers らの取扱いでは2,5)，熱による格子振動の効果 はいわゆる Debye Waller 因子 $\sigma^{2}$ を用いて, $\exp \left(-\sigma^{2} \mathrm{r}^{2}\right)$ という形で入っている. これは等方的な熱振動を仮定し ており，結合に異方性がある場合には各結合毎に考える 必要がある， 2 対分布関数を用いた取扱いなども報告さ れている. また，EXAFSの Debye Waller 因子はX線 回折の Debye Waller 因子と異なっていることを指摘し ておきたい. 即ち，EXAFS では，ある特定の結合の変 位の差の二乗平均であるのに対し，X線回折では原子自 身の二乗平均変位を意味している ${ }^{10)}$. 隣接原子と強く結 合している共有結合系では EXAFS の $\sigma^{2}$ はかなり小さ くなることが予想される.

(iv) 多原子励起効果

一般に電子がとびでる過程で, 残りが電場の急激な変 化を感じて励起状態に吒き上げられたり（shake-up過程 程), あるいは，外に飛びでる (shake-off 過程) という 多電子励起の現象が起こる. これによって, 電子の一部 はそれだけェネルギーを失らことになり EXAFSのシグ ナルに寄与しない. このような多電子励起効果に使われ る電子の割合は, 瞬閒近似を用いて光電子のとびでる前 後の残りの $(N-1)$ 電子系の波動関数 $\Phi_{\mathrm{N}-1}, \Phi_{N-1}^{\prime}$ の重

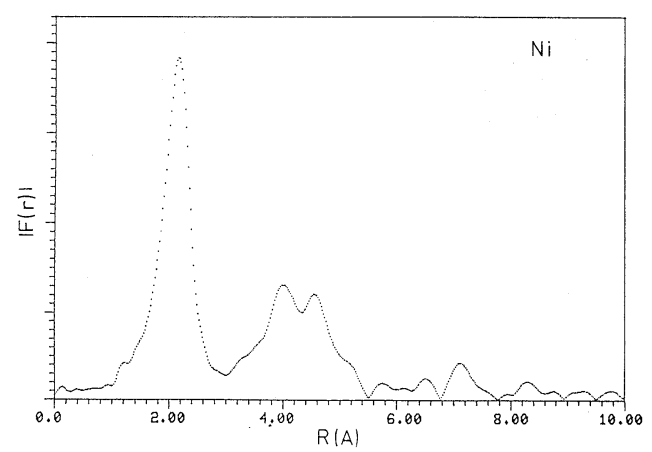

図 6 ニッケルの EXAFS スペクトルのフーリェ変 換

なり積分で表わされる.

$$
S_{0}^{2}=\left|\left\langle\Phi_{\mathrm{N}-1} \mid \Phi_{\mathrm{N}-1}^{\prime}\right\rangle\right|^{2}
$$

$S_{0}{ }^{2}=1$ ならば, 多電子励起効果は全然ないことを意 味するが，理論計算によれば，この $S_{0}^{2}$ の值は，電子の 運動エネルギーが $200 \mathrm{eV}$ 以上では $0.7 \sim 0.8 て ゙ あ り{ }^{12)}$, 原子の種類によって值が異なる. この多電子励起効果は EXAFS の振幅の減少に寄与するわけで，振幅の解析か ら得られる情報, 配位数 $N$ の誤差を大きくしている ${ }^{13)}$.

(v) 寿命と平均自由行程

EXAFS が現われるためには，中心原子の内殼に空孔 がある間に，散乱を受けた電子が戻ってくる必要があ る. 言い換えれば，空孔の寿命が後方散乱波と出射波の 干渉を起こすに十分な時間が必要である. 空孔寿命 $7 \times$ $10^{-16}$ 秒 (自然幅 $1 \mathrm{eV}$ に対応) の時間内に $100 \mathrm{eV}$ の電子 は $42 \AA$ 移動することができる. 重原子になる程, 内殼の 自然幅は大きくなる訳で*，それだけ外側の款からの EXAFS シグナルが消されてしまらことになる.

また, 電子が中心原子から飛びでた後, 固体中でプラ ズモンの生成に使われたり，オージェ電子の生成に使わ れたりすると，コヒーレンスを失い EXAFS を与えな いであろう。これは，見方を変えれば，出射電子は有限 の距離, 有限の時間しか有効でないことになる.このこ とはとり囲む原子が外側になればなる程 EXAFS への 寄与は小さくなることを意味し，EXAFS の本質的な限 界といえよう。

\section{3 表面 EXAFS}

EXAFS は本来，X線吸収分光法であり，試料を透過 する前後の X線強度の比から吸収係数を求める.この透 過法によって得られる EXAFS は, 試料の内部の構造 に関する情報を与えることになるが，これと別の方法で 吸収と等価な情報を得ることができよう。

図 7 に示したように，単色X線が入射し，試料中の原

* $\mathrm{Au}$ の $\mathrm{K}$ 殼は約 $30 \mathrm{eV}$ の自然幅をもつ 


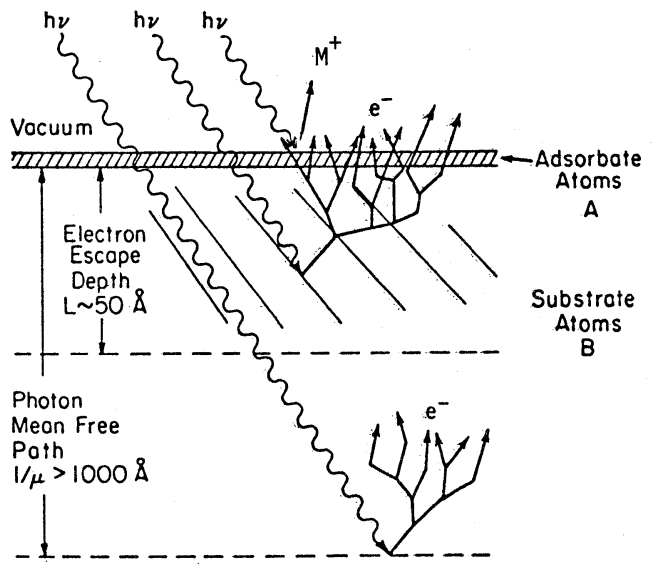

図 $7 \mathrm{X}$ 線の吸収によって引起こされるいろいろな 過程

子の内殼吸收が起こると, 光電子がとびだす ${ }^{7) 、 X ~} \mathrm{X}$ 線は 数十 $\mu \mathrm{m}$ の厚さまで物質内部に入ってゅくが, 電子は周 囲の原子による非弾性散乱を受けてエネルギーを失って ゆくため, 表面から外にとびだすのは数十丹以内のもの だけである. 内殼の光電子ピークを検出すれば EXAFS と同じ情報が得られるであろうか. 答は否である. 光電 子のとびだす角度の確率は運動エネルギーによって様々 に変化するが, 固体表面からはせいぜい $2 \pi$ の立体角し か検出できないため ${ }^{14)}$ である. しかし, 非弾性散乱を受 けてふらふらになって表面にでてきた電子の収量は, 既 に散乱の過程で等方化されているため, 吸收と等価であ ることが知られている.こうしてできたいわゆる二次電 子収量による EXAFS は表面から $50 \sim 100 \AA$ の構造を反 映している.

一方, 吸収によって生じた内殼空孔の緩和に伴った蛍 光やオージェ電子の収量も吸収と等価な情報を与える.

原子番号 $Z=30$ で蛍光とオージェ電子による緩和の確率 がほぼ等しく, Zがそれより大きくなると蛍光の確率が 増し, $Z>50$ で殆ど蛍光だけとなる. したがって, 微量の 重金属のまわりの構造などを知るには蛍光検出法は有効 な方法である. しかし, 試料中に検出すべき元素が多量 にある場合は EXAFS シグナルを与えなくなる。これ は蛍光と入射 $\mathrm{X}$ 線の脱出媣度が余り変らないためであ る. 即ち, 吸収の少ない波長の $\mathrm{X}$ 線は，それだけ深くま で侵入し, 結局, 同じだけの蛍光を生じてしまうからで ある。

これに対して，オージェ電子検出は軽元素では有効で あり, 脱出深度が数十 $\AA$ であるから, 表面感度の高い方 法でもある.オージェにも放出角度の運動エネルギー依 存性があるが，この場合は，ある特定のオージェピーク のみを検出する訳であり, 強度の相対的な変化が吸収に (o)

ADSORBATE EXCITATION
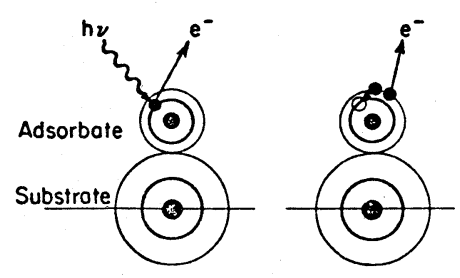

(0) +

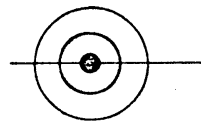

(b)

SUBSTRATE EXCITATION
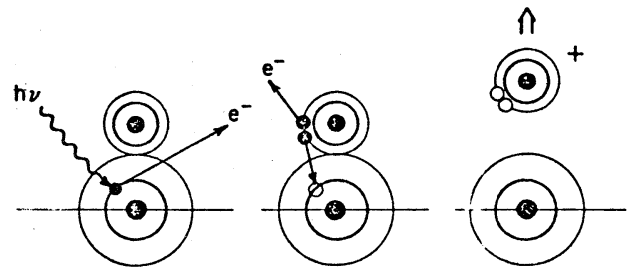

図 8 光脱離反応の $\mathrm{KF}$ モデル

(a) 原子内オージェ過程

(b) 原子内オージェ過程

比例することになり問題ない，しかし，入射X線の波長 掃引に伴って運動エネルギーの変化してゅく光電子のピ ークが，一定エネルギーのオージェピークに重なってく ると，EXAFS シグナルは大きく乱れてしまい，実用的 ではなくなる.

最近注目されている表面感度の高い方法として，PSD (Photon Stimulated Desorption) 法によるEXAFSがあ げられる. 光増感脱離の現象は未だ完全には確立されて いないが，比較的高いエネルギー領域（軟X線領域）で は，Knoteck と Feibelman による KF モデルで旨く説 明されている。 これは図8 ${ }^{7}$ に示したように，内殼吸収 によって起こるオージェ緩和がイオン脱離の起因である とする ${ }^{15)}$ もである.これには，原子内オージェ緩和に よるものと，原子間オージェ緩和によるものの 2 種類が ある. 前者は, 吸着原子そのもののオージェ緩和によっ てエネルギーをもらい脱離するタイプであり, 後者は, 基質に内殼空孔が生じたとき, これを埋める外殼電子が なくて，吸着原子からの原子価電子がそれにあてられる タイプである. いずれも, 脱離するイオンの周囲の構造 に関する情報を与えることになるが，これは，表面最上 層のものだけであり, 最も表面感度の高い方法といえよ 5.しかし, 残念なことに, このイオン脱離の確率は極 めて低いものであり, 後述するように特殊の工夫が必要 となる. 


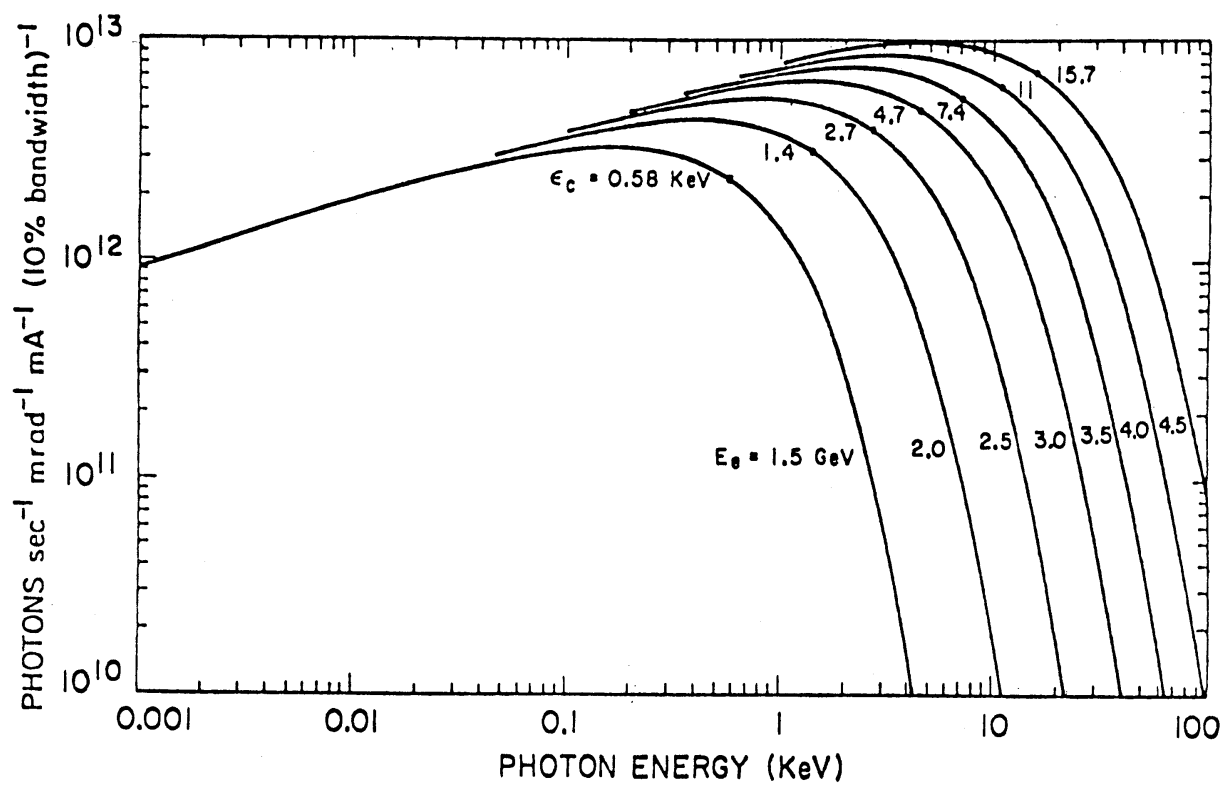

図 9 SPEAR に括ける放射光波長分布

\section{EXAFS の実験法}

\section{1 硬 X線光学系および EXAFS 実験装置}

透過法によってX線吸収スペクトルを測定するには， 白色 $\mathrm{X}$ 線光源から特定波長の $\mathrm{X}$ 線のみを結晶モノクロメ ーターによって取り出して試料を透過させる．入射前の ビーム強度 $I_{0}$ と試料透過後のビーム強度 $I$ を測定すれ ば，吸収係数 $\mu$ を次式により得る。ただし $t$ は試料の 厚みで EXAFS， $\chi(k)$ 導出には直接その值が知られてい なくても良い。

$$
\mu t(E)=\ln \left\{I_{0}(E) / I(E)\right\}
$$

光源としてX線管球のような制動放射を利用する場合 と放射光を用いる場合が考えられる，放射光を用いる場 合の利点は放射光が広い波長領域にわたって強度が $\mathrm{X}$ 線 管球よりも $10^{4} \sim 10^{6}$ 倍も強いことである. 放射光のスペ クトル分布は主としてストーレッジリングの電子のエネ ルギー, 曲率半径および電流值によって決まる。

図 9 にSSRL のストーレッジリングSPEAR の波長分 布 ${ }^{16)}$ を示した. 制動放射の波長分布にみられる特性線の 鋭いピークがない．放射光を用いた EXAFS 実験装置 の構成をフォトンファクトリーの場合を例として図10に 示す. 光源から約 $26 \mathrm{~m}$ 離れた地点に 2 枚の $\mathrm{Si}$ 結晶から なるモノクロメータがある. 光源から放射光はベリリウ ム空を通ってヘリウムガスが満たされたビームパイプ中 をモノクロメーターまで導かれる，入射ビームと透過ビ ーム強度, $I_{0}$ およびI はイオンチェンバーによって測定 される. 放射光は水平方向に強く偏光しているためモノ
クロメーターの 2 枚の結晶は縦型のゴニオメーター上に 置かれている. 図11に2 結晶モノクロメーターを示し た. 入射ビームと反射面のなす角度を $\theta_{B}$ ，モノクロメ ーター地点に括けるビームの発散を $\delta \theta_{r}$, 結晶の反射に よる回折線のひろがりを $\theta_{\omega}$ (Darwin width) とすると得 られるエネルギーおよびエネルギー分解能は次式であら わされる。

$$
\begin{aligned}
& E=6.2 / d_{h k l} \sin \theta_{B} \\
& \Delta E=E \delta \theta_{r} \cot \theta_{B}, \delta \theta_{r} \gg \theta w
\end{aligned}
$$

出射ビームは図11に示されるように入射ビームに平行 で，結晶間隔を $D$ とすれば高さが $2 D \cos \theta_{B}$ だけ異な る. モノクロメーターを走查して $\theta_{\boldsymbol{B}}$ を変化させた時, 試料にあたるビーム位置が常に一定になるようにイオン チェンバーおよび試料は上下微動台の上にのせモノクロ メーターに同期して上下微動するようになっている，ピ エゾ素子を用いた第 1 結晶の微調機構は(1) 2 枚の結晶を 平行に保つこと及び(2)逆にわずかに平行位置からずらす ことによって高次反射の影響を減らすために用いられ る. $\mu_{1}, \mu_{2}, \mu_{3}$ は各々第 1 イオンチェンバーのガス，チ ェンバー間の空気，第 2 イオンチェンバーのガスの吸収 係数で今第 1 イオンチェンバーのガスは $N_{2}$, 第 2 イオ ンチェンバーのガスは Ar を使用した場合 $\mu_{1} \sim \mu_{2}, \mu_{3} \gg$ $\mu_{1}$ である. 試料の吸收保数を $\mu_{s}$, 厚みを $d$ とし人射 ビームの強度を $I_{0}$ とすれば, 第 1 イオンチェンバーと 第 2 イオンチェンバーの出力 $i_{0}, i$ は次式によって与え られる.イオンチェンバーの原理を図12に示した。

$$
i_{0}=1-\exp \left\{-\mu_{1} t_{1}\right\}
$$




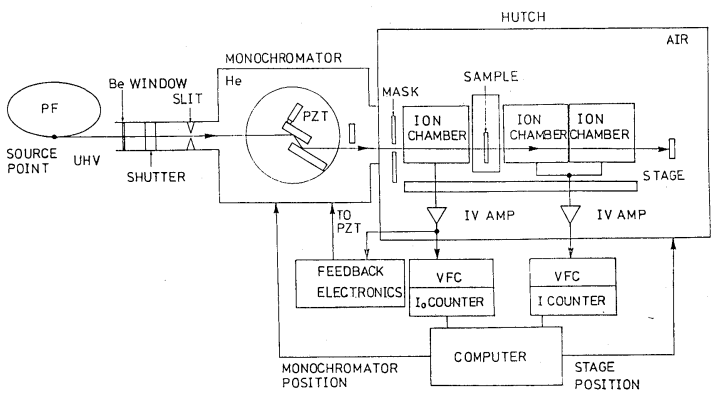

図10 放射光を用いた EXAFS 測定装置

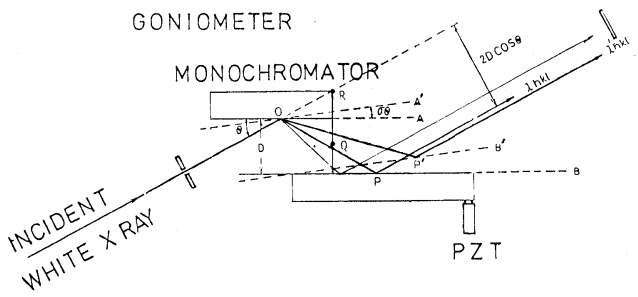

図11２結晶モノクロメーター

$$
\begin{aligned}
i= & \exp \left\{-\mu_{s} d\right\} \exp \left\{-\mu_{1}\left(t_{1}+\mathrm{t}_{2}\right)\right. \\
& \times\left\{1-\exp \left\{-\mu_{3} t_{3}\right\}\right\}
\end{aligned}
$$

ただし $t_{1}, t_{2}, t_{3}$ は第 1 イオンチェンバー, 空気, 第 2イオンチェンバーの厚みである.これらの比の対数を とると，

$$
\begin{aligned}
\ln & \left(i_{0} / i\right) \\
& =\ln \left\{\frac{1-\exp \left\{-\mu_{1} t_{1}\right\}}{\exp \left\{-\mu_{1}\left(t_{1}+t_{2}\right)\right\}\left(1-\exp \left\{-\mu_{3} t_{3}\right)\right.}\right\} \\
& +\mu_{s} d
\end{aligned}
$$

ここで第 1 項はイオンチェンバーのガスによる吸収の寄 与でエネルギーに対してなめらかに変化する単調な関数 である. $\mu_{s} d$ を実験的に得るためには試料のない状態で 同じ測定をくり返せば第 1 項が得られるのでこれを引け ば良い，次に吸収スペクトルの $\mathrm{S} / \mathrm{N}$ 比を最大にする試 料の最適厚みおよびイオンチェンバーの吸収量を考察す る。第 1 および第 2 イオンチェンバーによって吸収され るフォトン数を $N_{1}, N_{2}$ とする. 簡単のため各々 $N_{2}, \mathrm{Ar}$ ガスを用いるとする. 入射フォトン数を $N_{0}$ とすれば

$$
\begin{aligned}
N_{1} & =N_{0}\left(1-\exp \left\{-\mu_{1} t_{1}\right\}\right) \\
N_{2} & =N_{0} \exp \left\{-\mu_{2} t_{2}\right\} \exp \left\{-\mu_{5} d\right\} \\
& \times\left(1-\exp \left\{-\mu_{3} t_{3}\right\}\right) \\
\sim & N_{0} \exp \left\{-\mu_{2} t_{2}\right\} \exp \left\{-\mu_{5} d\right\}
\end{aligned}
$$

$S / N$ 比は次式であらわすことができる*.ただし空気 の吸収係数 $\mu_{2}$ を $\mu_{1}\left(N_{2}\right)$ で近似した.

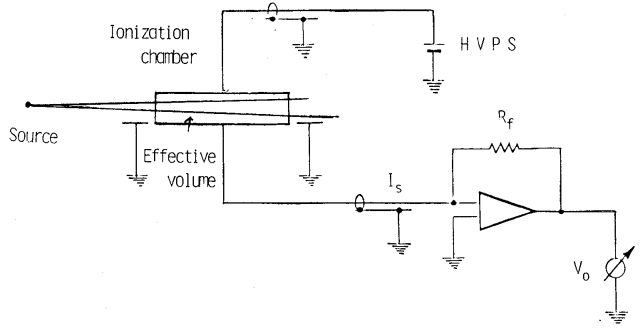

図12 イオンチェンバーの原理

$$
\begin{aligned}
& S / N=\text { const. } \times d\left(\frac{\partial \mu_{s}}{\partial E}\right) \times N_{0}^{1 / 2} \\
& \quad \times\left[\frac{1}{1-\exp \left\{-\mu_{1} t_{1}\right\}}+\exp \left\{\mu_{1} t_{2}\right\} \exp \left\{\mu_{s} d\right\}\right]^{-1 / 2}
\end{aligned}
$$

両辺を $\mu_{1}, \mu_{s}$ で微分して 0 と置き連立させて解くこ とにより $S / N$ 比を極大にする $\mu_{s} d=2.68, \mu_{1} t_{1}=0.16 か ゙$ 得られる.このよらにして吸収スペクトルの $S / N$ 比は $I_{0}$ 測定用のイオンチェンバーと試料の厚みによって決ま ることがわかる。

成分原子濃度が低い場合は厚み $d$ を大きくしても, 、 トリックスの吸収が大きいため透過光は極めて弱くなり $S / N$ 比は減少する. そこで放射光の強度をもってして も透過法で微量成分原子の吸収スペクトルを測定するの には限度がある。これに対し蛍光X線の収量が吸収係数 に比例することを利用すれば透過法では測定不可能な極 微量成分の EXAFS が測定できる17). エネルギーEを 持つ単色X線を試料に対して $45^{\circ}$ をなす角で入射させ入 射ビームからの $90^{\circ}$ の角度においた検出器によって測定 される蛍光X線の強度 $I_{f}$ は次式であらわすことができ $ろ^{17)}$.

$$
\begin{aligned}
I_{f}= & I_{0} \varepsilon_{f}(\Omega / 4 \pi) \mu_{i}(E) \int_{0}^{d} \exp \left\{-\left\{\mu_{T}(E)+\mu_{T}\left(E_{f}\right)\right\} t\right\} \\
& \times \mathrm{d} t \\
= & I_{0} \frac{\varepsilon_{f}(\Omega / 4 \pi) \mu_{i}(E)}{\mu_{T}(E)+\mu_{T}\left(E_{f}\right)}\left\{1-\exp -\left\{\left[\mu_{T}(E)+\mu_{T}\left(E_{f}\right)\right] d\right\}\right.
\end{aligned}
$$

ここで $\Omega$ は検出器を試料が見込む立体角, $\varepsilon_{f}$ は蛍光収率, $I_{0}$ は入射ビーム強度， $\mu_{i} ， \mu_{T}$ は各々励起される成分打よ び試料全体の吸収係数, $d$ は試料の 厚み, $E_{f}$ は蛍光 $\mathrm{X}$ 線のエネルギーとする. $i$ 成分原子の濃度の小さい極限 では $\left[\mu_{T}(E)+\mu_{T}\left(E_{f}\right)\right] d \gg 1$ であるから $I_{f}$ は近似的に次 式であらわせる.

$$
I_{f} \sim I_{0} \frac{(\Omega / 4 \pi) \varepsilon_{f} \mu_{i}(E)}{\mu_{T}(E)+\mu_{T}\left(E_{f}\right)}
$$

$$
\begin{aligned}
& * N=\Delta\left(N_{1} / N_{2}\right)=\left(N_{1} / N_{2}\right)\left[\left(\frac{\Delta N_{1}}{N_{1}}\right)^{2}+\left(\frac{\Delta N_{2}}{N_{2}}\right)^{2}\right]^{1 / 2}=N_{1} / N_{2}\left(\frac{1}{N_{1}}+\frac{1}{N_{2}}\right)^{1 / 2} \\
& S=\text { const. } \times \frac{\delta}{\delta E}\left(\frac{N_{1}}{N_{2}}\right)=\text { const. } \times d\left(\frac{N_{1}}{N_{2}}\right) \times \frac{\delta \mu_{s}}{\partial E}
\end{aligned}
$$




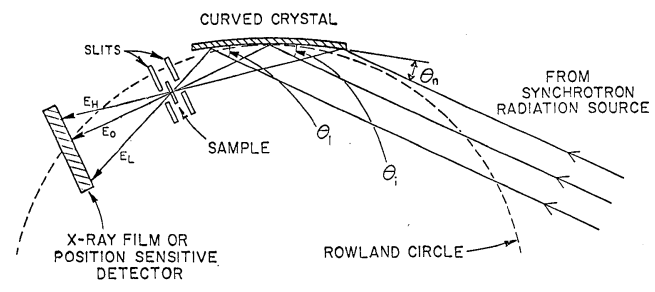

図13 エネルギー分散 EXAFS 測定装置

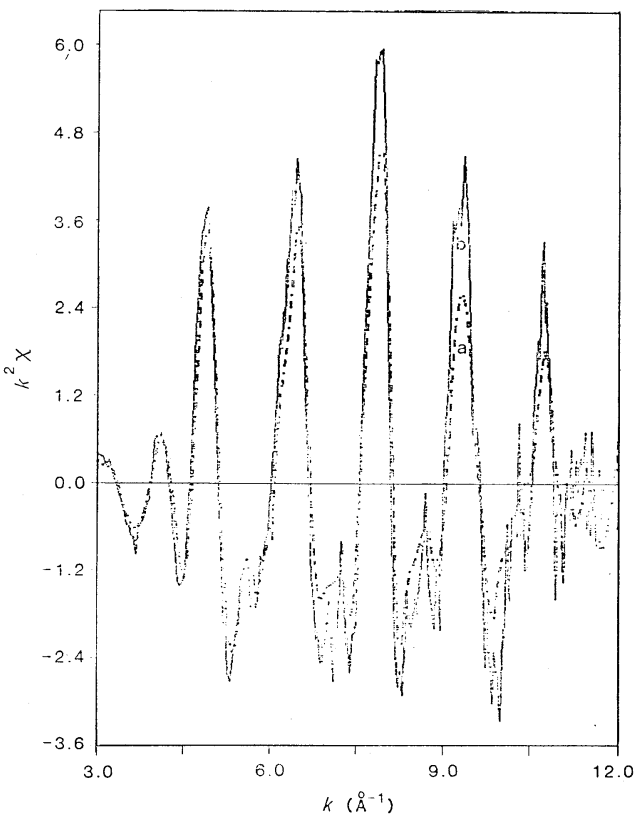

図14鉄のエネルギー分散 EXAFS スペクトル

(a)は角度走查型，(b)はエネルギー分散型

$\mu_{T}\left(E_{f}\right)$ は定数であり， $\mu_{T}(E)$ はエネルギーに対しゆる やかに変化するから $I_{\boldsymbol{f}}$ の測定から $i$ 成分原子の $\mathrm{EXAF}$ $\mathrm{S}$ を得ることができる. 現在用いられている蛍光 EXA FS 測定装置では有効な立体角 $\Omega$ をできるだけ大きく $S / N$ 比良く蛍光線を検出するための工夫がこらされて いる ${ }^{18 \sim 21)}$.

今まで説明してきた方法はいずれもモノクロメーター によって単色化されたビームを用いており，吸収スペク トルを得るためにはモノクロメーターを走査させる必要 があるため刻々時間変化をする系や時間分解を必要とす る過度的な現象への応用には都合が悪い. これに対して エネルギー分散 EXAFS (EDEXAFS) は広いエネル ギー範囲にわたって吸収スペクトルを同時に 测 定でき $ろ^{22,23)}$ ために高速な実験に適している．図13はその光学 系である放射光からの平行性の良いX線をワン曲結晶に よって収束しその焦点位置に試料を置く.

透過 X線強度を試料後方に置いた位置敏感検出器 ( P

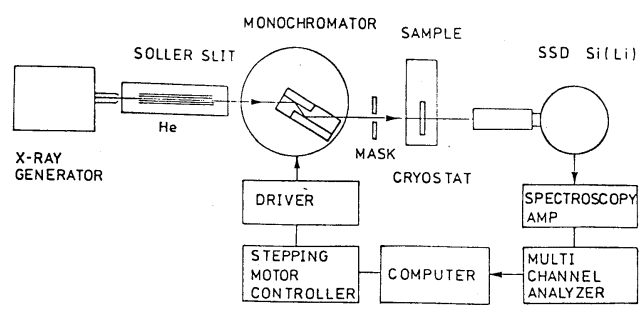

図15 実験室におるけ EXAFS 測定装置

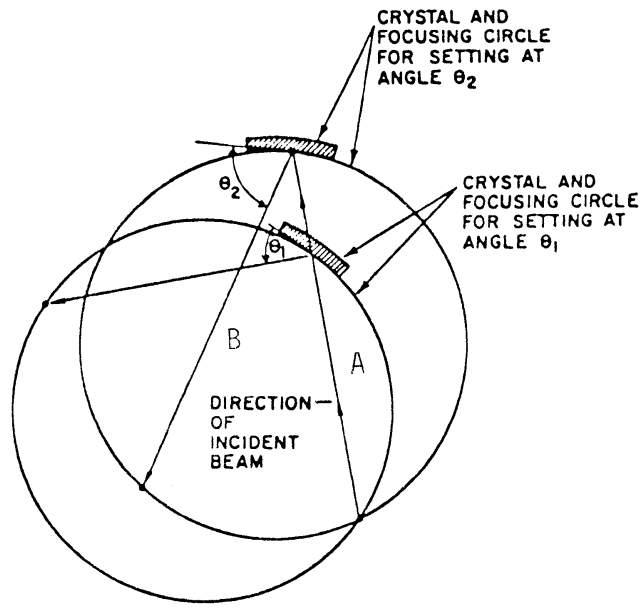

図16湾曲結晶を用いた集光モノクロメーター

SD) により測定する. モノクロメーター結晶として Si (111)を用いて，1000 eV 程度のエネルギー範囲を $2 \mathrm{eV}$ 程度のエネルギー分解能 $(\mathrm{Cu} \mathrm{K}$ 吸収端付近) で, 測定 することができる. PSD として写真フィルムを用いた 場合 $2.5 \mathrm{GeV}, 50 \mathrm{~mA}$ で約 $0.1 \sim 1$ 秒でスペクトルが得 られる (図14).PSD として高位置分解能を持つフォト ダイオードアレイを用いれば $1 \sim 2$ 秒程度の時間分解能 での動的な EXAFS 測定が可能となるので, 化学反応 等への応用が期待されている. さらに放射光のパルス性 に着目すれば, くり返し起こる現象では $10 \sim 100^{+1}$ 秒程 度の時間分解能を持つ実験が可能であろう。

実験室系の EXAFS 測定系の例を図15に示した. 平板 結晶によるモノクロメーターでもモザイク結晶を用いた り非対称カット結晶により積分反射能を増やすことが可 能であるが図16に示されるようなワン曲結晶を使えば $10^{2}$ 倍程度強度を上げることができる ${ }^{24)}$. このような測 定系ではビーム強度はもはや NaI シンチレーション検 出器では測定できない程強いためイオンチェンバーが用 いられる。.このような実験装置を用いれば数時間で測定 が終わるため, 比較的濃度の高い試料を実験室内で簡便 に得られるので, 今後も放射光の利用と並行して使われ ていくであろう. 


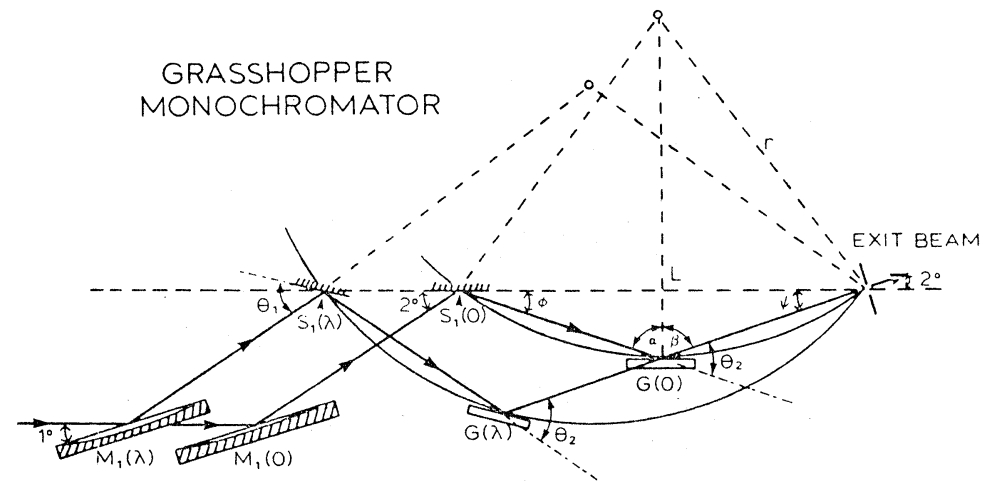

図17(a) グラスホッパー分光器の光学系 ( $\mathrm{a}$ と b両方一緒)

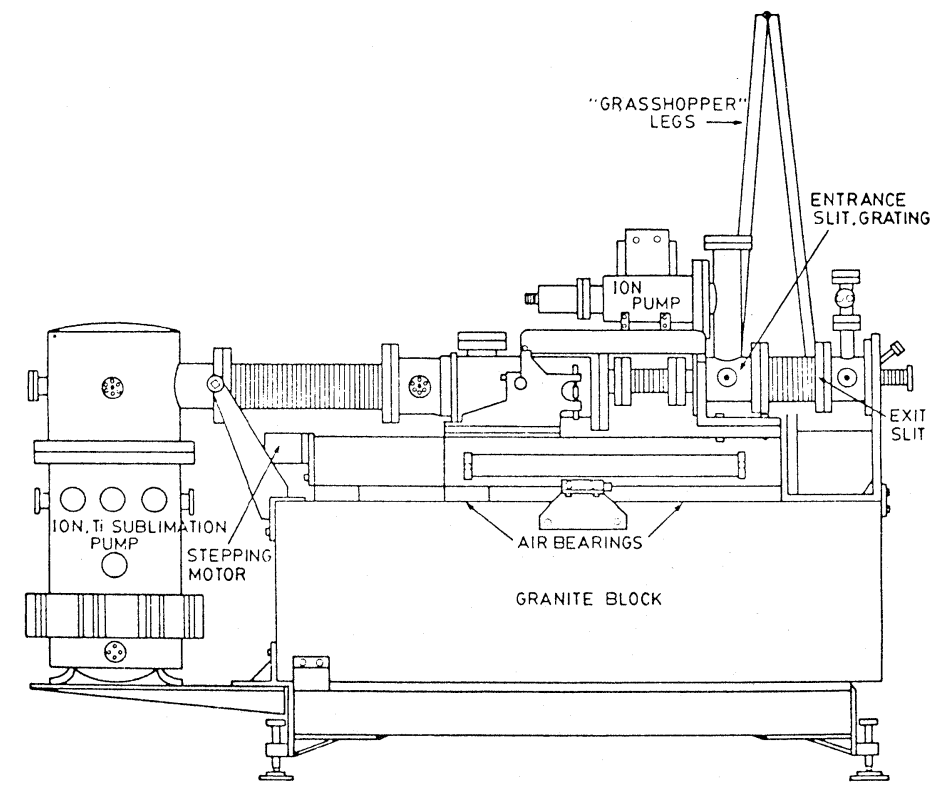

図17(b) グラスホッパー分光器の概観

\section{2 軟 $\mathbf{X}$ 線光学系}

軟 $\mathrm{X}$ 線領域の光源は, これまで, $\mathrm{Cr}, \mathrm{Ti}, \mathrm{Al}, \mathrm{Mg}, \mathrm{C}$ の $\mathrm{K}_{\alpha}$ 線， $\mathrm{Y}, \mathrm{Zr}$ の $\mathrm{M}_{\zeta}$ 線などが用いられているが，特 性X線のエネルギーはとびとびであり，制動放射による 連続X線の強度は極めて小さい, EXAFS の実験には波 長可変な単色光源が必要であり, これらの光源は満足で きるものとは言えない，放射光がこの領域をカバーする 強力な光源として登場してからは, まさに放射光の独壇 場になっている. 放射光の強度の波長分布はストーレッ ジ・リングをまわる電子のエネルギー, 電子の曲率半径 に依存しているが, 高工研放射光実験施設の場合 $(E=$ $2.5 \mathrm{GeV}, R=8.66 \mathrm{~m}) 4 \sim 40 \AA$ の軟X線領域が最も強度 が大きい.

EXAFS の実験では，この連続光源を単色化する分光
器が必要であるが，ちょうど軟X線領域は回折格子によ る分光と結晶分光のギャップにあたる困難な 領 域であ る. 即ち, 回折格子を用いる斜入射分光器は $10 \AA$ 以下に なると回折効率が落ち, しかも, 散乱光, 迷光が増えて くるので，実用的でなくなる.

一方, 分光結晶では, 格子間隔が大きく, 軟 $\mathrm{X}$ 線領域 に吸収端をもつ元素をもたない単結晶材料が必要とされ る. 残念ながら現在では, 軟X線の広い波長領域をカバ 一する単結晶はみつかっていない，また，放射光を光源 とする場合は, 軟 X線領域でよく用いられるステアリン 酸鉛や, KAP, KDP などの有機結晶は輻射によるダメー ジをすぐに受けるため使用できない.

現在, 軟 X線領域で最も活躍している分光器はスタン フォードの放射光実験 施 設 (SSRL) のグラスホッパー 


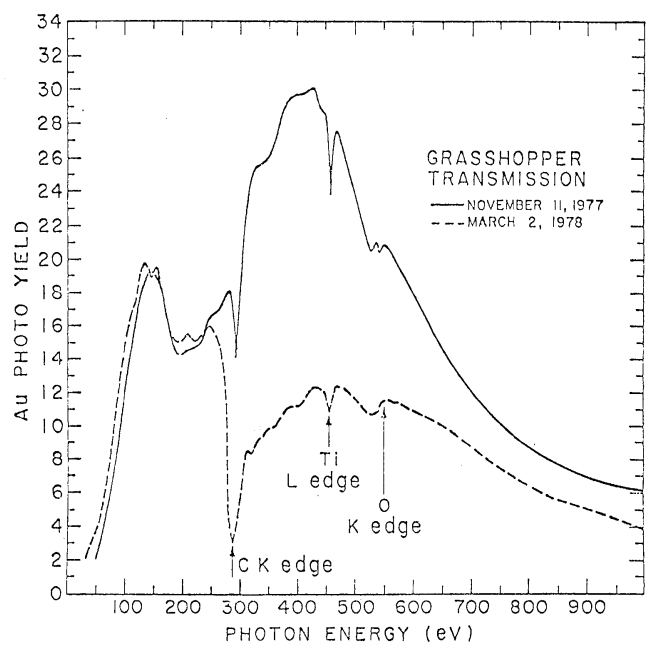

図18 グラスホッパー分光器の透過率

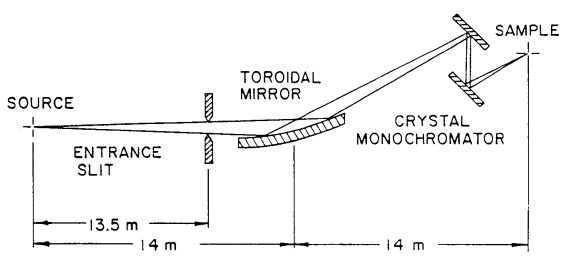

(a) CRYSTAL MONOCHROMATOR BRANCH LINE

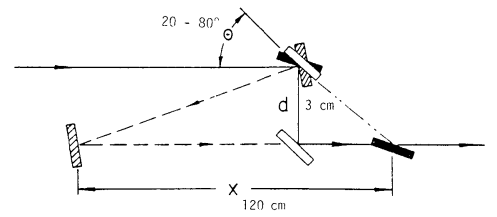

(b) $\frac{\text { CRYSTAL MONOCHROMATOR }}{\text { (SIDE VIEW) }}$

図19 軟X線二結晶分光器の光学系

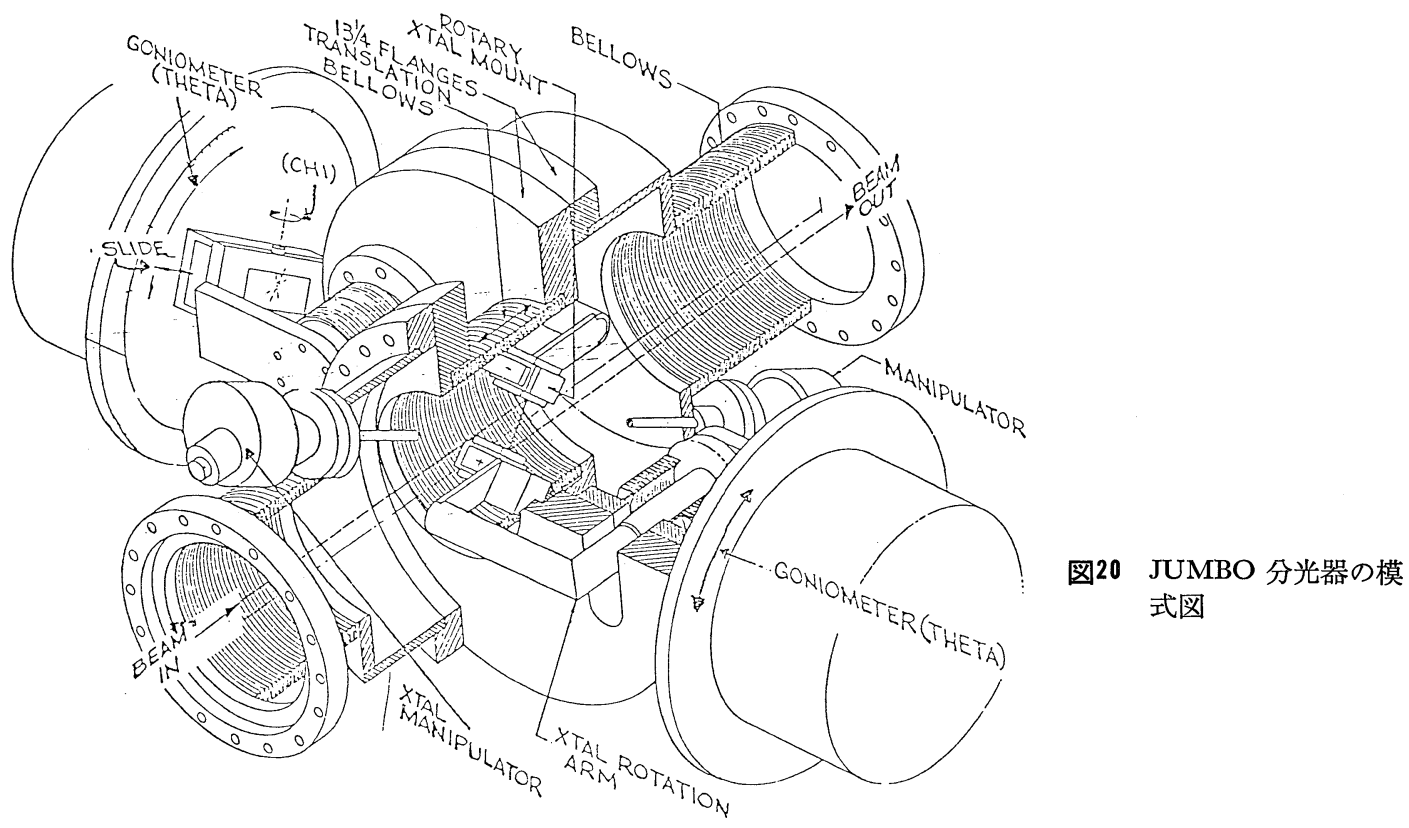

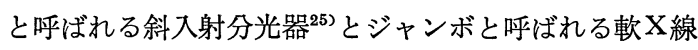
二結晶分光器 ${ }^{26)}$ である. グラスホッパー分光器の光学系 は図17に示したよらであり，ローランド円 $2 \mathrm{~m}$ の面回 折格子を用いている. 溝本数 $600 \mathrm{l} / \mathrm{nm}$ の 回折格子を用 いるとき, 得られる光子のエネルギー依存性は図18のよ 5 になる27). 光学系の污れによって, $\mathrm{C}, \mathrm{O}, \mathrm{Ti}^{*}$ による 吸収が現われている，利用できるエネルギーは $50 \mathrm{eV〜}$ $1 \mathrm{keV}$ であり，それ以上では散乱光，迷光が支配的にな る. この分光器では， C, N, Oなど表面状態の研究に重

\footnotetext{
*) Ti の吸収はチタンサブリメーションポンプによる.
}

要な元素の K吸収をカバーすることができ, 興味深い. ジャンボと呼ばれる分光器は図19のような光学系にな っている二結晶分光器であるが, 単色化されたビームを 固定するよう，一方の結晶には回転以外に並進機構も持 たせてある. この分光器の特徵は, 超高真空仕様になっ ており，更に，四種の結晶の組を in situ で交換できる ようにして利用できる波長範囲を広げていることであ る. ジャンボの模式図 ${ }^{26}$ を図20に示した，波長の掃引は ゴニオメータの回転をベローズを介して鍵型のアームに より，真空内の結晶に伝えることによって行う．結晶の 


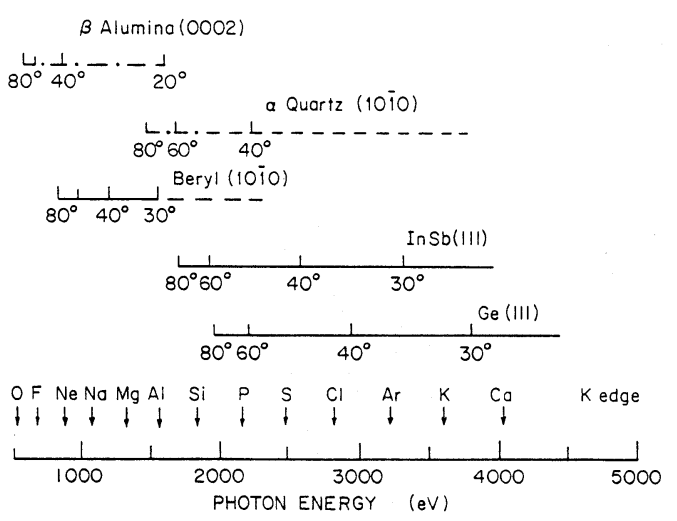

図21 軟 $X$ 線領域で利用できる分光結晶とその可能 なエネルギー範囲

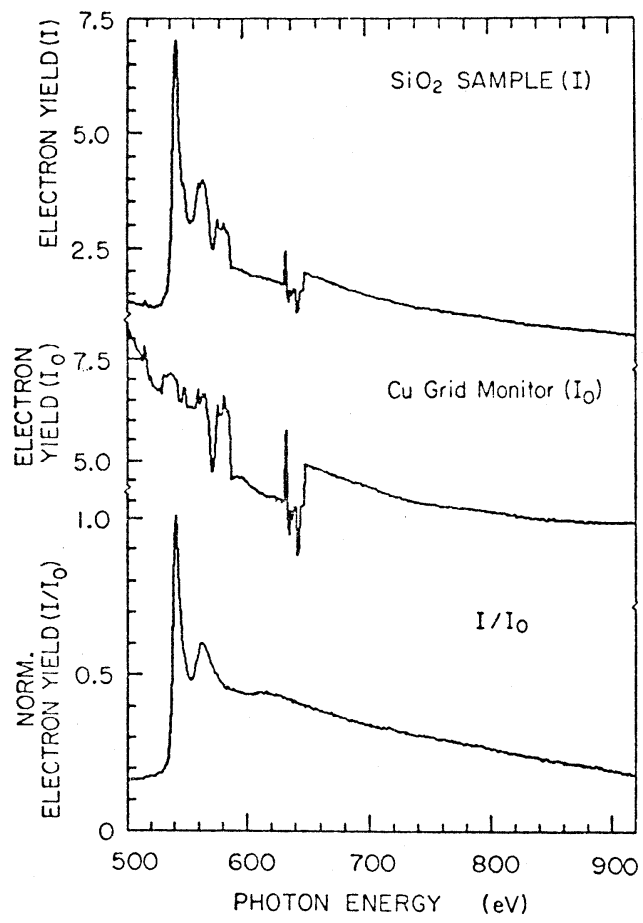

図23 $I_{0}$ モニターを用いた $\mathrm{SiO}_{2}$ のO の EXAFS

並進は大きなベローズにより，エアベアリング上をゴニ オメータも一緒に動くことによって行う．全体としてか なり大きな分光器でジャンボと呼ばれる由縁である。結 晶としては, ベリル $\left(\mathrm{Be}_{3} \mathrm{Al}_{2}\left(\mathrm{SiO}_{3}\right)_{6}\right), \mathrm{InSb}, \alpha$-石英, $\mathrm{Ge}, \mathrm{GGG}^{* *}$ などが用いられる。これがカバーできる波 長範囲 ${ }^{28)}$ を図24に示した。

これら以外にも，ブルックヘブンで数種の軟 $\mathrm{X}$ 線二結 晶分光器の製作が進行しており, 高工研放射光実験施設 でも, 新しいタイプの分光器の製作が進められている.

\footnotetext{
**) ガドリウム・ガリウム・ガーネット
}

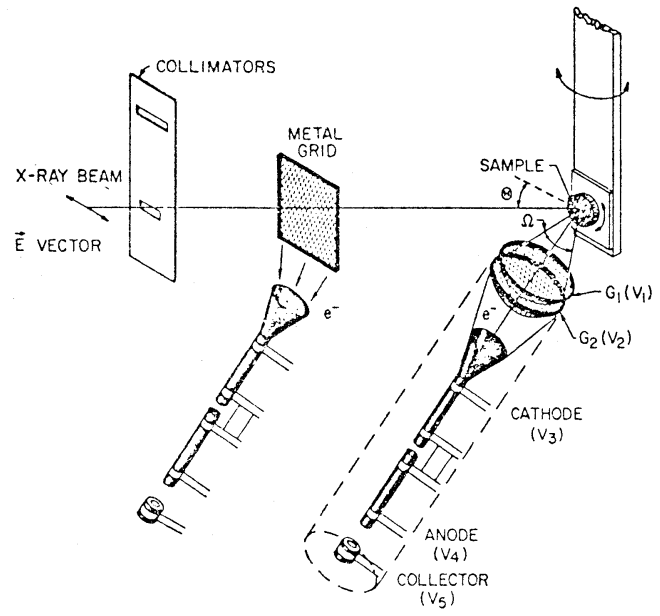

図22 二次電子収量法による SEXAFS

\section{3 表面 EXAFS 測定法}

二次電子収量法による表面 EXAFS は, 図22に示し たように, 電流モードのスパイラルトロンを用い, ピコ アンメータによる検出という, 極めて簡単な方法で可能 となる7． $I_{0}$ モニターとしては金属メッシュからの光電 子を同様に電流増幅して検出する. 金属メッシュ材料と しては, 測定範囲で吸収端がなく，なだらかな吸収をも つ金属が望ましい. $200 \sim 900 \mathrm{eV}$ では $\mathrm{Cu}$ グリッド, 1 $\mathrm{keV}$ 以上では, $\mathrm{Au}$ グリッドが用いられる?.

$I_{0}$ の測定は, 不安定な放射光光源を用いるような場合 は必要不可欠である。図23に Si の K 吸収 EXAFS の $I_{0}, I, I / I_{0}$ のスペクトル7) を示した. 図中, $I_{0}, I$ の急 激な落ち込みは, ストーレッジ・リングのビームの不安 定性による.

オージェ電子検出法による表面 EXAFS では, 電子 エネルギー分析器が必要となる. 通常, CMA が使われ 図24のような構成になる ${ }^{29)}$. この方法は, 二次電子収量 法に比べると表面感度が高い. 両者を比較した例 ${ }^{293}$ を図 25に示した. しかし, 光エネルギー掃引によって, 光電 子ピークがオージェピークを横切れば，満足な EXAFS

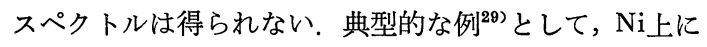
Oが吸着した系で図26に示した. このような現象は比較 的エネルギーの低い領域で EXAFS を測定しようとす れば必然的に起こる問題である。したがって，C，N, O のような軽元素の表面 EXAFS には, 二次電子収 量 法 が用いられ, 数 $\mathrm{keV}$ 領域では, オージェ電子検出法が すぐれていると言えよう。

一方, PSD 法による表面 EXAFS 測定は, イオン光 脱離の確率が極めて小さいため, 四重極マスフィルター のようなイオン検出の方法は用いることができない. 


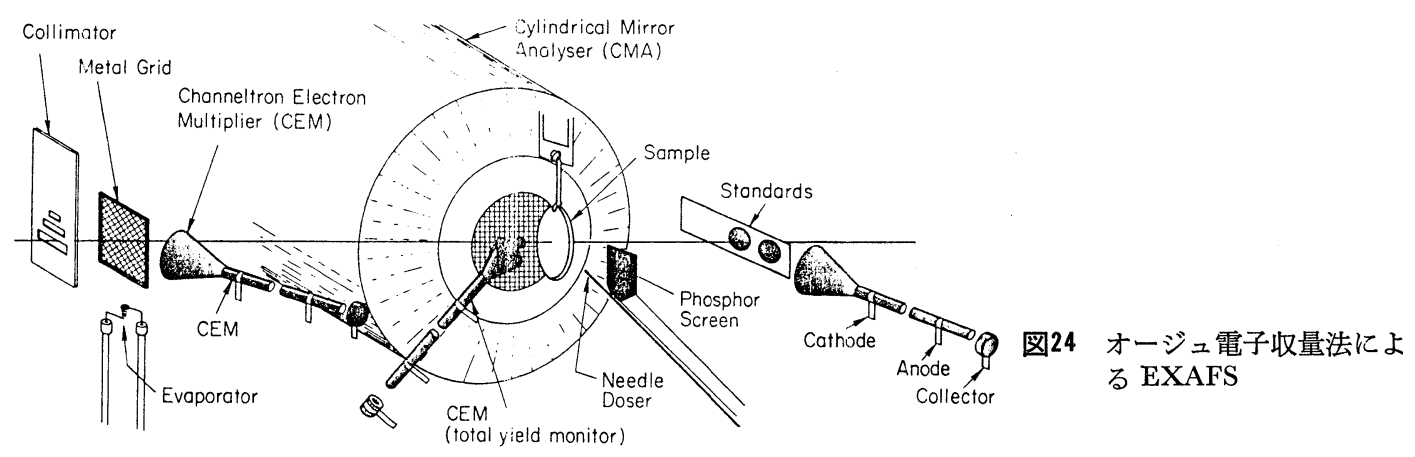

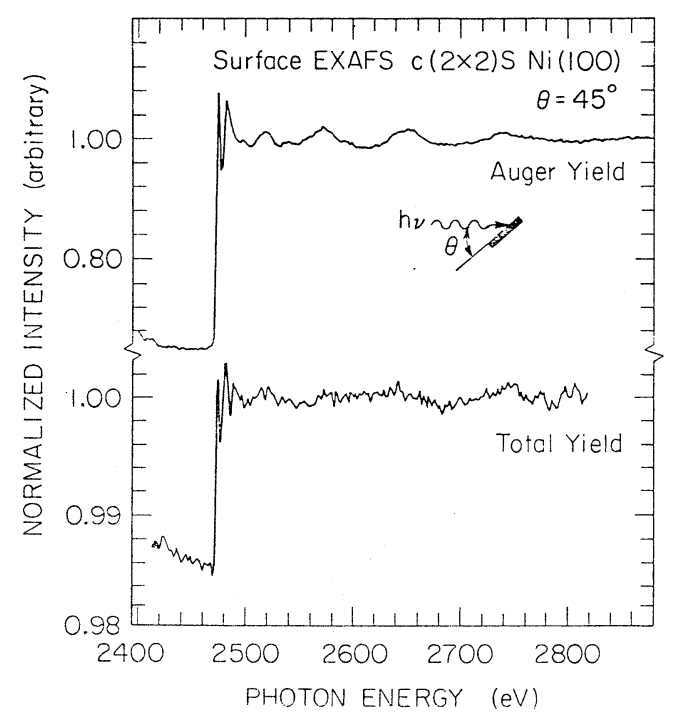

図25 オージェ電子収量法と, 二次電子収量法の比 較. 試料は $c(2 \times 2) \mathrm{S} / \mathrm{Ni}(100)$ で, $\mathrm{S} \mathrm{K}$ 吸収の EXAFS を示す.

Knotek らは SSRL で，放射光のパルス性を用いて， 飛行時間差法によってイオンを検出している. その構成 は図27のよらになっている7，幸い，スタンフォードの ストーレッジ・リングでは通常単一バンチ運転を行って おり，パルス間隔が約 $780 \mathrm{~ns}$ ある. 光脱離のイオンスペ クトルの例") として, 表面の污れた Mo(100)試料につい て図28に示した。 ここで， $\mathrm{O}^{+}$の位置だけに空を開け て, 光の波長を掃引すれば, 酸素の吸着したサイトの周 囲の EXAFS と等価なスペクトルが得られる. 図29に, $\mathrm{O} / \mathrm{Mo}(100)$ 系で, $\mathrm{Mo}$ の $\mathrm{L}$ 吸收端での $\mathrm{O}^{+}$イオンスペ クトル ${ }^{7,28)}$ を, 二次電子収量スペクトルと比較して示し た.

\section{EXAFS の解析法}

図30は室温で測定された Fe フォイル $(10 \mu \mathrm{m})$ の $\mathrm{Fe}$ K吸収スペクトルである。

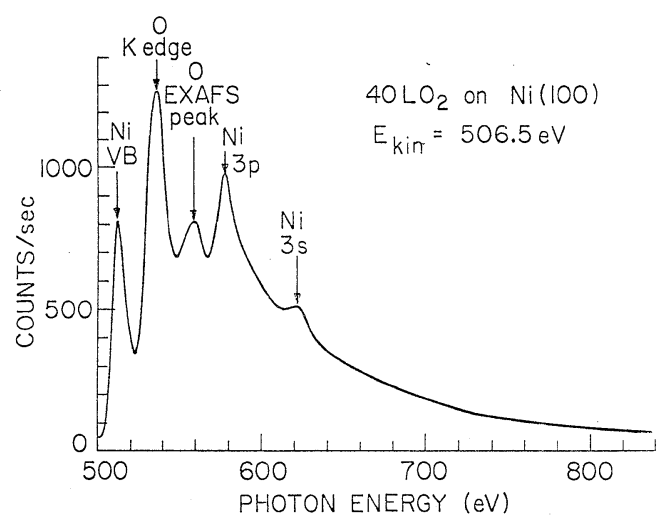

図26表面酸化された $\mathrm{Ni}$ のオージェ電子収量スペ クトル

吸収端の鋭い立ち上がり (7-11 keV) から高エネルギ 一側に観測される振動構造が EXAFS である. 全体の 吸収係数はK殼による項とそれ以外の部分に 分けられ る.

$$
\mu^{\mathrm{Tot}}=\mu_{0}{ }^{\mathbf{K}}+\Delta \mu^{\mathbf{K}}+\mu^{\mathbf{L}}=\mu_{0}{ }^{\mathbf{K}}(1+\chi)+\mu^{\mathbf{L}}
$$
$\mu_{0}^{\mathrm{Tot}}, \mu_{0}^{\mathrm{K}}, \Delta \mu^{\mathrm{K}}, \mu^{\mathrm{L}}$ は各々全体の吸収倸数, 原子の $\mathrm{K}$ 殼, EXAFS，L 殼の吸収係数をあらわす.

吸収端より低いエネルギー領域は金属 $\mathrm{Cu}$ のように単 体では L 凯による吸収であるが化合物では, 他成分原子 のL殼あるいはK殼の寄与が重なっている. 元素の $\mathrm{K}$ 吸 收端同士は $1 \mathrm{keV}$ 以上離れていることが多く $\mathrm{K}$ 吸収スペ クトルが重なることは少ない. したがって EXAFSでは 注目する原子の $\mathrm{K}$ ，あるいは L吸収端を調べることによ ってその原子のまわりを独立に調べることができる.

\subsection{EXAFS の規格化}

吸収係数を直接扱らかわりに密度で割った質量吸収係数 $(\mu / \rho)$ を用いると元素によって一定の値となり便利であ る. $\mu / \rho$ を使って全質量吸収係数は次のようにあらわす ことができる. $(\mu / \rho)_{i}$ は $i$ 成分の質量吸収係数, $g_{i}$ は質 量分率である。

$$
\mu / \rho=\sum_{i} g_{i}(\mu / \rho)_{i}
$$




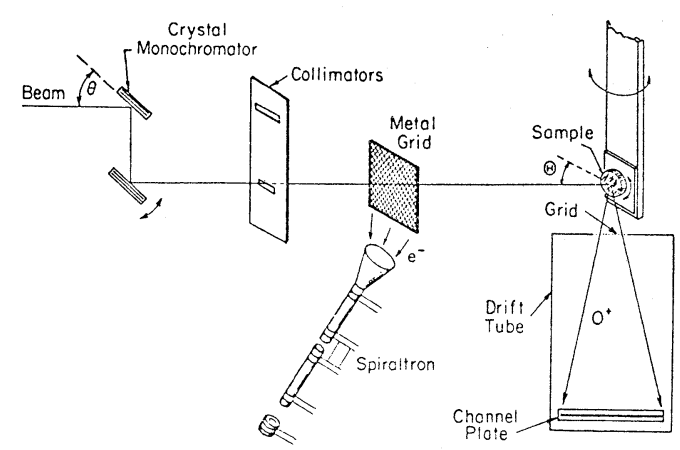

図27光脱離イオン収量法による SEXAFS

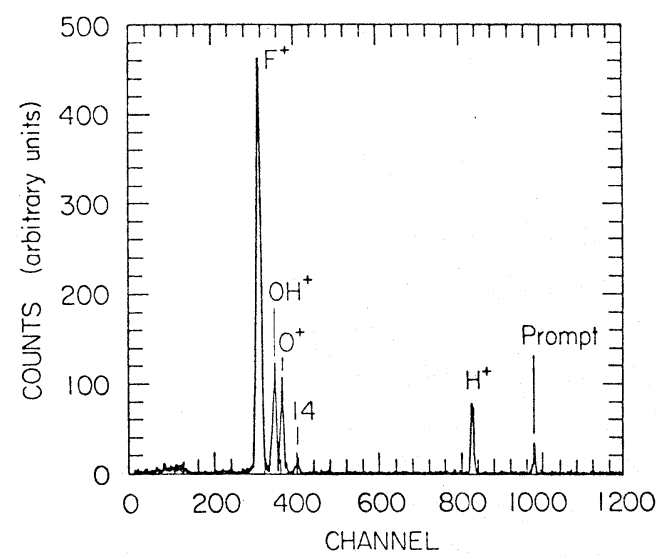

図28 Mo 表面からの光脳離イオンの質量スペクト ル

また $(\mu / \rho)$ は は Victoreen の関係式を用いて次のよら にあらわせる30)

$$
\begin{gathered}
(\mu \mid \rho)_{i}=C_{i} \lambda^{3}-D_{i} \lambda^{4}+\sigma_{\mathrm{KN}} N Z \mid A \\
\sigma_{\mathrm{K}-\mathrm{N}}=\frac{8 \pi}{\alpha} \cdot \frac{e^{4}}{m^{2} c^{4}} \cdot \frac{3}{4}\left[\frac { 1 + \alpha } { \alpha ^ { 2 } } \left\{\frac{2(1+\alpha)}{1+2 \alpha}\right.\right. \\
\left.-\frac{1}{\alpha} \ln (1+2 \alpha)\right\}+\frac{1}{2 \alpha} \ln (1+2 \alpha) \\
\left.-\frac{1+3 \alpha}{(1+2 \alpha)^{2}}\right]
\end{gathered}
$$

ただし $\alpha=h v_{0} / m c^{2}$

$\sigma_{\mathrm{KN}}$ は Klein-Nishina の表式による自由電子の散乱 による吸収断面積で，通常のエネルギー範囲 (4-30 keV) では第 1,2 項に比べて無視できる. 各々の原子種に対 して $C_{i}, D_{i}$ の值は与えられている ${ }^{30)}$. 吸收端より低エ ネルギー側を Victoreen の式でフイットすれば $\mathrm{K}$ 殼によ る吸収部分を分離することができる．図30に吸収端より 前の領域を引き去った $\mathrm{Fe}$ 吸収スペクトルを示した， $\mathrm{E}$ $\mathrm{XAFS}$ を求めるには(1)固体中の弧立原子による吸収を 差し引いた後規格化し，(2)ェネルギーを波数 $k$ に変 換 する。図31中の実線で示された部分が EXAFS のバッ

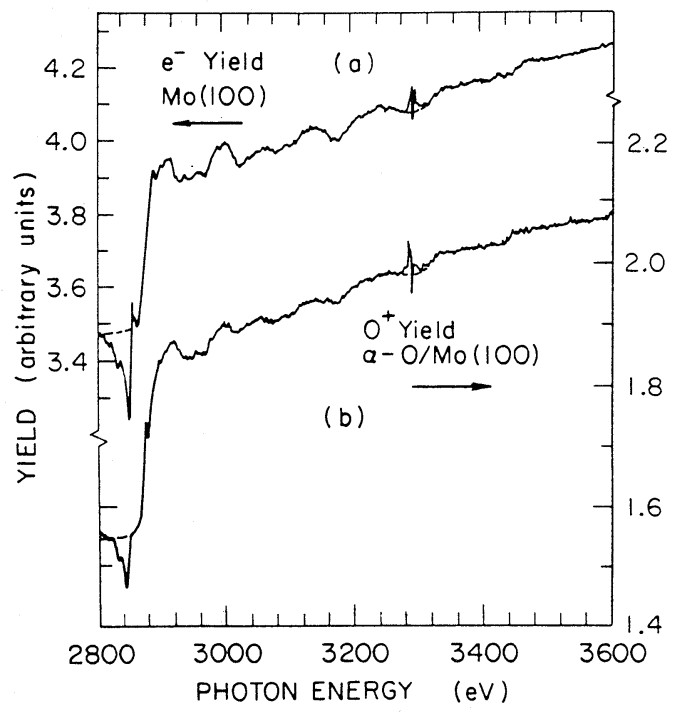

図29 (a) Mo(100) 面の電子収量法による SEXAFS (b) $\alpha-\mathrm{O} / \mathrm{Mo}(100)$ の $\mathrm{O}^{+}$イオン収量法による SEXAFS

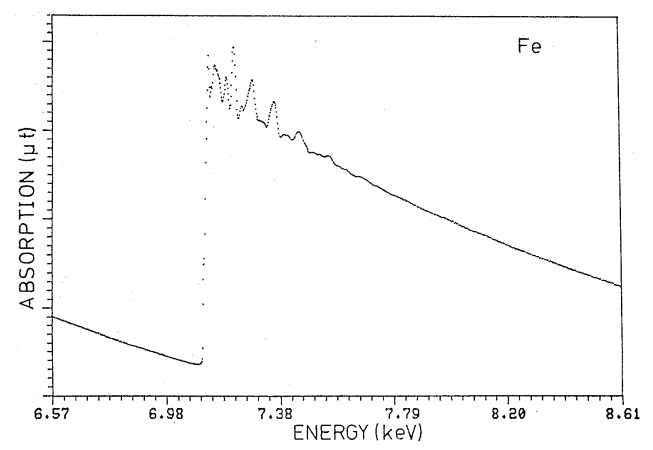

図30 金属鉄の FeK 吸収スペクトル

クグラウンドでエネルギーに対してなめらかに減衰して いく.

実際にこのような弧立原子によるバックグラウンドを 引き去るには(1)スプライン関数*) で一定区間のバック グラウンドを近似してそれらをなめらかにつないでい く, (2)低次多項式で全ての領域を一度あるいは遂次に近 似していく，(3)ーリェフィルター法により低周波成分 を分離して最初のバックグラウンドを補正するなどの方 法がある. 多項式フィット法と組み合わせた遂次フーリ

\footnotetext{
*) 与えられた区間でデータ間をなめらかに結ぶ関数で, 連続条件とし ては一次微分を用いる. 高次多項式の最小二乗法によるフィットに 比ベて端のデータやノイズなどにあまり影響されないといら利点を 有する.
} 


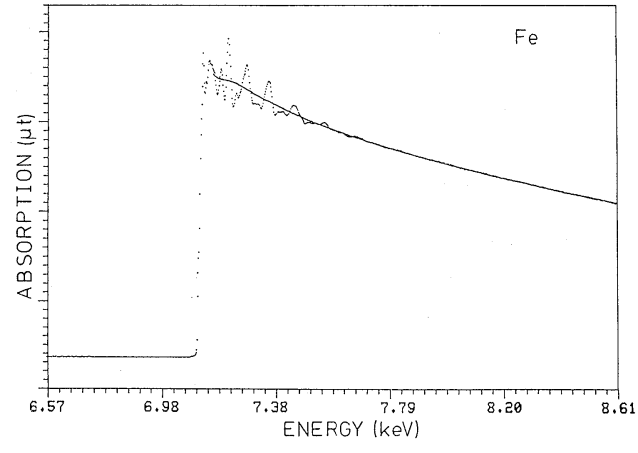

図31 吸収端により前の部分を引き去った Fe K 吸 収スペクトル

エフィルター法について説明する.この方法は(2)と(3)を 組み合わせたものである.

まず(2)の低次多項式 $P_{\mathrm{m}}(E)=(\mathrm{m}=2,3)$ によってバッ クグラウンドを近似して実験データに最も良くフィット する係数を求める。

このためには最小 2 乗法による線形パラメータ推定の アルゴリズムが使われる. $\mathrm{m}$ 次多項式 $P_{\mathrm{m}}(E)=a_{0} E^{0}+$ $a_{1} E^{2}+\cdots \cdots a_{\mathrm{m}} E^{\mathrm{m}}$ でデータの組 $\left(E_{i}, Y_{i}\right)(i=0, \mathrm{n})$ を含む 領域を近似する. 多項式の係数 $a_{0}, a_{1} \cdots \cdots a_{\mathrm{m}}$ は $Q=\sum_{i}$ $\left[P_{\mathrm{m}}\left(E_{i}\right)-Y_{i}\right]^{2}$ が最小になるように決める.これには係 数行列の逆行列を求めるか Gauss-Jordan 法で連立一次 方程式を解けば良い.

この時次数を高くとると行列の Determinant が 小さ くなり発散する，基底として直交関数系（例えば離散 Legendre 多項式を使えば，この問題は改善される. 多項 式によるフィットの便利な点は関数系が簡単であること だが，データの端やノイズに影響されやすい. スプライ ン関数 ${ }^{31)}$ の方法ではノット（節）を適当に選ぶことによ りこの久点は除くことができる. 一般に低次多項式近似 ではうまくフィットできないため, 次に遂次フーリエフ イルターを行ら。(2)で得られたバックグラウンドから $\mathrm{E}$

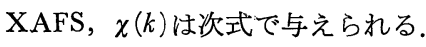

$$
\frac{Y-\left(P_{0}+\Delta P\right)}{P_{0}+\Delta P}=\chi_{0}+\Delta \chi
$$

ここで $Y$ は $\mathrm{K}$ 殼による吸収， $P_{\mathbf{0}}$ は(2)によるバックグラ ウンドである. 右辺第 1 項は $P_{0}$ による項, $\Delta \chi$ は補正 項 $\Delta P$ による項である.

$$
\begin{aligned}
& \chi_{0}=\frac{Y-P_{0}}{P_{0}+\Delta P} \\
& \Delta \chi=\frac{-\Delta P}{P_{0}+\Delta P}
\end{aligned}
$$

新しい $\chi$ を $\chi^{\prime}$ とすれば $\chi^{\prime}$ は次式により求めることがで

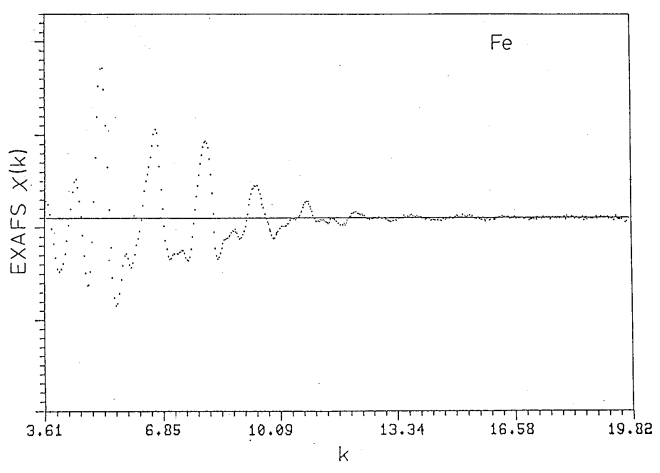

図32金属鉄の Fe K EXAFS

きる.

$$
\chi^{\prime}=\frac{Y-P_{0}}{P}=\frac{Y-P(1+\Delta \chi)}{P(1+\Delta \chi)}
$$

$\Delta \chi$ を求めるには後述するフーリエフィルターといら手 法が用いられる. 今 $\Delta \chi$ を最初のフーリエフィルターで 求めたとすれば次に $Y-P$ の $P$ の代りに $P(1+\Delta \chi)$ を 代入する. この操作を $\Delta \chi \rightarrow 0$ になるまで遂次くり返す. このよらにして得られた $\chi(k)$ を図32に示した. 我々の 経験ではスプライン関数によるフィットが最も任意性が 少なく良い結果が得られるようである.

線のエネルギーを $h v ，$ フェルミ準位から測った $\mathrm{K}$ 殼のエネルギーを $E_{B}{ }^{F}$ とすると光電子の波数 $k$ は次式 で与えられる*).

$$
\frac{\hbar}{2 m}^{2} k^{2}=h v-E_{\mathbf{B}} \boldsymbol{F}-E_{\mathbf{0}}
$$

ここで $E_{0}$ は “inner potential” と呼ばれ，ポテンシャ ルの零值を決めるパラメータである. 金属ではその物理 的意味はマフィンティンポテンシャルの原点から測った フェルミ準位のエネルギーと考えられる. (1)内殼準位の 結合エネルギーにも化学シフトがあり, (2)価電子状態に よって $E_{0}$ も影響を受ける．また(3)半導体や絶縁体では フェルミ準位が不確定であるなどの理由から一義的に決 めずに物質によって適当な值を調節することが望まし い，LEEDに㧍ける内部ポテンシャル $V_{0}$ と $E_{0}$ は仕事関 数の差だけ異なる（図33）。 $E_{0}$ を決めるためには次の 2 つの方法がある.

(1)計算による位相シフトを考慮してフーリエ変換を行 い，実際のピーク位置にフーリエ変換のピーク位置が一 致するように選ぶか，(2)フーリエ变換の虚部のピークが 絶対值のピークに一致するように選ぶ8).

\section{2 フーリエ変換}

図33の $\chi(k)$ に次のような複雑フーリエ変換を行った

* (8)式の $E_{b}$ は, ここでの $E_{B}{ }^{F}+E_{0}$ に相当する. 


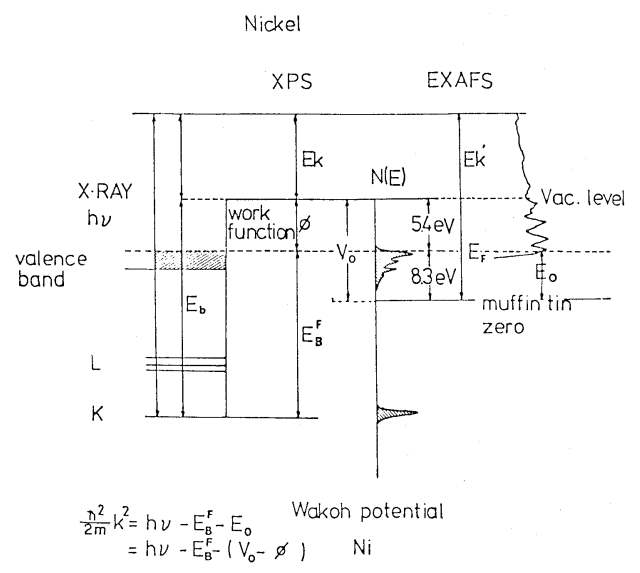

図33 金属 $\mathrm{Ni}$ のエネルギー準位図

結果を図34に示した.

$$
\begin{aligned}
F(r)= & \int_{\mathrm{k} \min }^{\mathrm{kmax}} W(k) k^{n} \chi(k) \mathrm{e}^{-2 i k r} \mathrm{~d} k \\
= & \int_{\mathrm{k} \min }^{\mathrm{kmax}} W\left(k() k^{n} \chi(k) \cos (2 k r) \mathrm{d} k\right. \\
& -i \int_{\mathrm{kmin}}^{\mathrm{kmax}} W(k) k^{n} \chi(k) \sin (2 k r) \mathrm{d} k \\
= & R_{e} F(r)+i I_{m} F(r) \quad(n=1,3)
\end{aligned}
$$

$W(k)$ は打ち切り効果を最少にするような空関数で例え ば Gaussian で幅をつけたステップ関数などを用いて両 端でなめらかに減衰するようにする，我々は $W(k)$ とし て両端で正弦関数的に減衰するものを用いている.

$$
\omega(k)=\left\{\begin{array}{cc}
\frac{1}{2}\left[\cos \left\{\frac{k-k_{1}}{k_{0}-k_{1}} \pi\right\}+1\right] & \left(k_{0} \leq k<k_{1}\right) \\
1 & \left(k_{1}<k \leq k_{2}\right) \\
\frac{1}{2}\left[1-\cos \left\{\frac{k-k_{3}}{k_{2}-k_{3}} \pi\right\}\right] & \left(k_{2} \leq k<k_{3}\right)
\end{array}\right.
$$

図33に示されるフーリェ変換では $E_{0}=5.0 \mathrm{eV}$ とし $k_{0}, k_{1}, k_{2}, k_{3}$ はそれぞれ3.0，4.0，12.0，13.0 $\AA^{-1}$ であ る.この例では $n=1$ のフーリエ変換を行っているが $n$ $=3$ もよく使われる. $n=1$ ではピークの幅は広いがリッ プルは目立たない，これに対して $n=3$ では $k$ の大きい 領域のデータが強調されてピークは鋭くなる，2つのピ 一クが 1 部重なっている時にそれを分離するには $n=3$ の方が便利である．ただし実空間の分解能はフーリェ変 換の際の $k$ の範囲によって決まる.

図34には $1 \sim 5$ 番目までのピーク位置が示されてい る. 各々のピーク位置は実際の原子位置より0.1 0.2A 小さいがこれは散乱の位相シフトによるものである. 吸 収原子と散乱原子の和である全位相シフト $\phi_{\text {Tot }}$ は $k$ の 1 次式として近似され， $\phi_{0}, \phi_{\mathrm{sc}}$ を各々吸収原子, 散乱原 子の位相シフトとすれば, これらの和であらわされる.

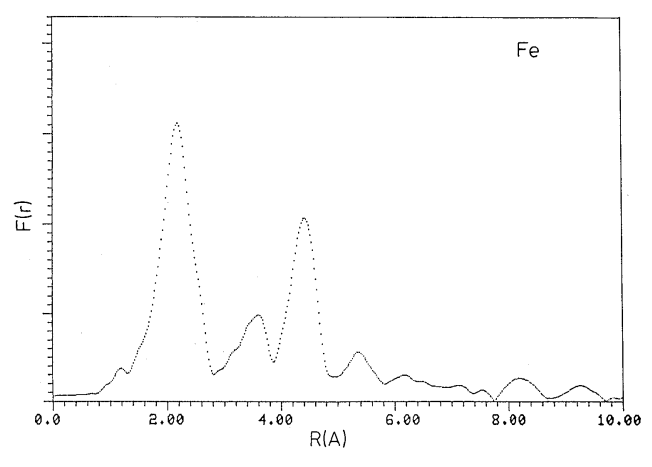

図34 金属鉄の Fe K EXAFS のフーリエ変換

$$
\phi_{\mathrm{Tot}}=\phi_{0}+\phi_{\mathrm{sc}}=c_{0} k+c_{1}
$$

そこで位相シフトを無視してフーリエ変換した時のピー ク值を $R$ とすれば実際の原子位置 $R_{0}$ よりも $c^{0} / 2$ だけず れることになる*).

$$
R=R-\Delta R, \Delta R=\frac{1}{2} c_{0}
$$

\section{3 カーブフィットによる解析}

位相シフトや散乱振幅の補正なしのフーリエ変換によ って原子分布の大よその形を知ることはできるが，リッ プルや打ち切り効果等フーリエ変換自身の問題もあって 精度良く配位数, 結合距離, Debye-Waller 因子を求め ることは困難なことが多い，そこで現在では直接フーリ 工変換の結果からではなく, 実空間32)あるいは $k$ 空間 上 ${ }^{33)}$ で実験データを最も良く再現できるような構造パラ メーターの組を探すカーブフィット法が用いられる. こ のためには散乱の位相シフトや後方散乱振幅がわかって いることが必要である. 理論計算の散乱振幅よりを実験 の振幅は約 $50 \%$ む小さい ${ }^{111}$ ためスケーリング因子 $N_{0}$ を パラメーターとして構造のわかっている結晶であらかじ め $N_{0}$ を決めて拧く，位相シフトとして理論值を使うこ ともできるが，ここでは，実験的に決めたものを用いる ものとする. 全体の $\chi(k)$ は $\alpha$ 種吸収原子のまわりの $i$ 種 散乱原子による $\chi_{\alpha i}(k)$ の寄与の和として次のようにあら わすことができる.

$$
\begin{aligned}
& \sum_{i} \chi_{\alpha i}(k)=\sum_{i} \frac{1}{k r_{\alpha i}{ }^{2}} N_{0} E_{\alpha i} * A_{\alpha i}(k, \pi) \\
& \quad \times \sin \left(2 k r+\phi_{\alpha i}(k)\right) \times \exp \left(-\sigma_{i}{ }^{2} k^{2}\right) \\
& A_{\alpha i}(k, \pi)=\left|f_{i}(k, \pi)\right| \exp \left(-\gamma_{i} r_{\alpha i}\right), \gamma_{i}=2 / \lambda_{i} \\
& \phi_{\alpha i}(k)=2 \delta_{\alpha}+\operatorname{Arg}\left[f_{i}(k, \pi)\right]
\end{aligned}
$$

ここで $N_{0}$ は $A_{\alpha i}(k)$ として理論值を使った時のスケ ーリング因子, $N_{\alpha i} *$ は有効配位数, $r_{\alpha i}$ は結合距離, $\sigma_{i}$ は Debye-Waller 因子である. 光学ポテンシャルによって この場合は光電子の非弾性散乱による減衰をあらわすパ

* 理論の項参照. 
ラメーター $\gamma_{\alpha l}$ を含んでいる. 位相シフト $\phi_{\alpha i}(k)$ は吸収 原子抒よび散乱原子による寄与の和として次式で近似す る.

$$
\phi_{\alpha i}(k)=a_{0}+a_{1} k+a_{2} k^{2}+a_{3} k^{-3}
$$

実験的に $\phi_{\alpha l}(k)$ を決めるには試料に近い構造 のモデ ル化合物の実験データに最む良くフィットするよう $N_{0}$, $a_{0}, a_{1}, a_{2}$ を決めればよい．これには最小 2 乗法による非 線型パラメーターフィットの手法を用いる. 一般に関数 $F\left(E_{i}, C_{0}{ }^{0}, C_{1}^{0}, \cdots \cdots C_{\mathrm{m}}{ }^{0}\right)$ が $\left(C_{0}, C_{1}, \cdots \cdots C_{\mathrm{m}}\right)$ をパラメー ターとする変数 $E_{i}$ の関数でデータ $Y_{i}\left(E_{i}\right)$ の近似となっ ている時初期パラメーター $\left(C_{0}^{0}, C_{1}{ }^{0}, C_{\mathrm{m}}\right)$ のまわりに 1 次の Taylor 展開を行うと,

$$
\begin{aligned}
& F\left(E, C_{0}, C_{1}, \cdots \cdots C_{\mathrm{m}}\right) \doteqdot F\left(E, C_{0}{ }^{0}, C_{1}{ }^{0}, \cdots\right. \\
& \quad+\frac{\partial F}{\partial C_{0}}\left(C_{0}-C_{0}{ }^{0}\right)+\frac{\partial F}{\partial C_{1}}\left(C_{1}-C_{1}{ }^{0}\right)+\cdots \cdots \\
& \quad+\frac{\partial F}{\partial C_{\mathrm{m}}}\left(C_{\mathrm{m}}-C_{\mathrm{m}}{ }^{0}\right)
\end{aligned}
$$

そこで両辺から $Y_{i}$ を引けば残差 $r_{i}$ は次式であらわせ る.

$$
r_{i} \sim R_{i}+\frac{\partial F_{i}}{\partial C_{0}} \delta C_{0}+\cdots \cdots+\frac{\partial F_{i}}{\partial C_{m}^{0}} \delta C_{\mathrm{m}}(i=0, n)
$$

ここで $\delta C_{K}=C_{K}-C_{K}{ }^{0},\left.\frac{\partial F_{i}}{\partial C_{K}}\right|_{E=E_{i}, C_{k}=C_{k}{ }^{0}}, R_{i}$ は初期 值とデータの残差である.

$$
R_{i}=F\left(E, C_{0}{ }^{0}, C_{1}{ }^{0}, \cdots \cdots C_{\mathrm{m}}\right)-Y_{i}(i=0, n)
$$

$r_{i}$ の平方和 $Q$ を最小にするようなパラメーターの組を求 める.

$$
Q \equiv \sum_{i} r_{i}^{2}=\sum_{i=0}^{n}\left[R_{i}+\frac{\partial F_{i}}{\partial C_{0}} \delta C_{0}+\cdots \cdots+\frac{\partial F_{i}}{\partial C_{\mathrm{m}}} \delta C_{\mathrm{m}}\right]^{2}
$$

$Q$ は $\delta C_{K}$ に関する全ての偏微分係数が同時に 0 になる 時最小值をとる.

$$
\begin{aligned}
\frac{\partial Q}{\partial\left(\delta C_{\mathrm{K}}\right)}= & 2 \sum_{i}^{n}\left(R_{i}+\frac{\partial F_{i}}{\partial C_{0}} \delta C_{0}+\cdots \cdots+\frac{\partial F_{i}}{\partial C_{\mathrm{m}}} \delta C_{\mathrm{m}}\right) \\
& \times \frac{\partial \Delta}{\partial\left(\delta C_{\mathrm{K}}\right)}=0
\end{aligned}
$$

ただし，

$$
\Delta=\frac{\partial F_{i}}{\partial C_{0}} \delta C_{0}+\cdots \cdots+\frac{\partial F_{i}}{\partial C_{\mathrm{m}}} \delta C_{\mathrm{m}}
$$

とする. 正規方程式を解いて得た 初期値 $C_{0}{ }^{0}, C_{1}{ }^{0}, \cdots C_{\mathrm{m}}{ }^{0}$ の組に対する補正值 $\delta C_{\mathbf{K}}(k=0, m)$ を用いて同様の操 作を行ら。これを順次くり返してある一定值に収束した らその時のパラメーターを推定值とする.

$N_{0}$ をスケーリング因子として一度決めた後, 目的の 試料で使うためにはモデル化合物の電子状態が, 試料の ものに近いことが望ましい，これは位相シフトがポテン

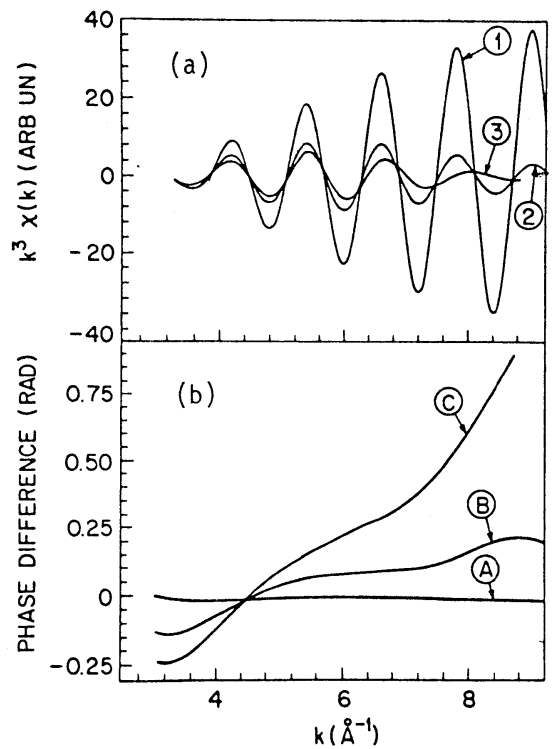

図35 非調和熱振動による位相のずれの効果 (a)(1) 10K, (2) 200K, (3) 285K における金属 Zn の ZnK EXAFS および(b)(A) 100K, (B) 200K, (C) 285K における位相のずれ

シャルの深い所の形で決まり結合状態にあまりよらな (*) のに対して散乱振幅は化合物によって多少変化す る34) からである．図 4 及び図 5 に種々の原子に対する理 論計算の位相シフトおよび散乱振幅を示した. 全体の位 相シフトは中心原子の位相シフト $\phi_{\alpha}$ と散乱原子の位相 $\phi_{i}$ の和である. 散乱振幅は $5 \sim 8 \AA^{-1}$ に極大を持ち散 乱原子種のみによって決まるため実験的に配位している 原子種を推定することもできる

$N_{0}, a_{0}, a_{1}, a_{2}, a_{3}$ が決まれば，次にこれらを使って試 料の実験データを最も良く再現するように配位数 $N_{\alpha i}$ 結 合距離 $r_{\alpha i}$, Debye-Waller 因子を決める. EXAFS にお ける Debye-Waller 因子は相対的な熱平衡位置からのず れをあらわし，回折における值よりは原子間の相関の分 だけ小さい(10). そこで我々は $N_{0}, a_{0}, a_{1}, a_{2}, a_{3}$ を決める 時に Debye-Waller 因子もパラメーターに入れて全部で 6 個のパラメーターを同時に動かして実験データをフィ ットした. 得られた Debye-Waller 因子は Beni-Platzman の式を用いて計算された值に良く一致した. もし ここで理論的な振幅を用いずに実験的に振幅を決めよう とすると振幅のパラメータと Debye-Waller 因子の相関 が大きく, 結果的に得られた Debye-Waller 因子の物理 的意味はうすれる点に注意されたい.

最近, 非調和熱振動あるいは非対称な原子分布の効果 でみかけ上フーリエ変換のピークが内側へシフトすると

*1つの系から他の系への移行性(chemical transferability)が成立す る. 


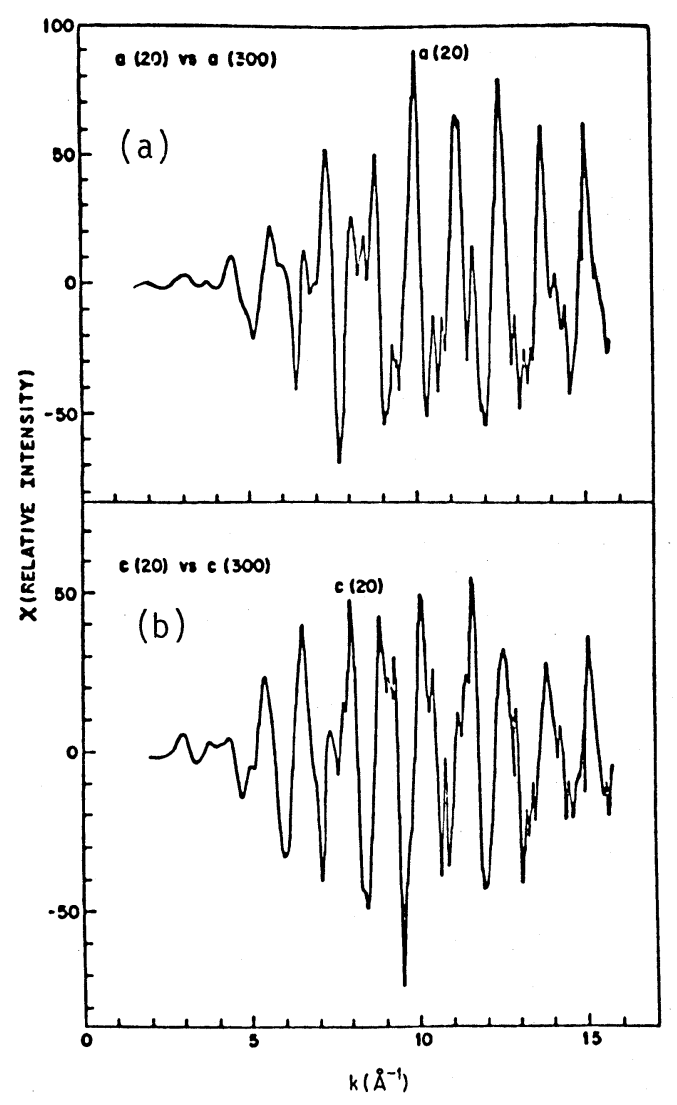

いらことが報告されている ${ }^{35)}$. 図35上段は $\mathrm{Zn}$ 金属の(1) 10K, (2)200K，(3)285KにおけるZn K-EXAFS である. 低温では熱振動が減少するため $\chi(k)$ の振幅が大きい が, $R>7$ の領域で高温側のデータとわずかに位相がずれ

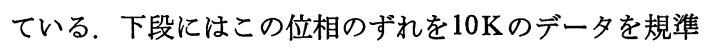
にして比較した. (A), B)，(Cは各々100K，200K，285K における位相のずれで，100K以下では小さいが常温付 近ではかなり大きくピーク位置で最大 $0.1 \AA$ の誤差をも たらす. この効果は非調和振動によるものと考えられて いるが結合距離を正確に決める場合, 特に原子の熱振動 が非調和的であれば低温で測定しなければならないこと を示している.

EXAFS は注目する原子のまわりの局所的な原子配列 を調べることができるため，その構造研究への応用はこ れまで他の手法では直接的な情報を得ることができなか った分野 (表面, 溶液, 生体物質, 触媒, 非晶質等) を 対象にして活発に行われている. 本稿ではそれら全てを 紹介することはできないので, 各分野で典型的な実験を 選びそれらについてできる限り詳しく説明した上で, 特 異的な問題点についてふれたい.

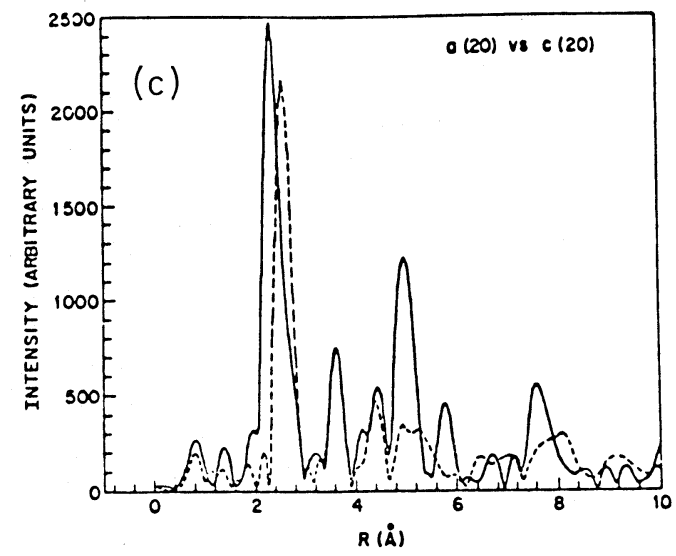

図36 金属 Zn の ZnK EXAFS の偏光依存性 (a)電場ベクトルが a 軸に平行な場合, (b) c 軸に平行 な場合の EXAFS スペクトルおよび(c)フーリエ変 換. 実線は(a), 点線は(b)に対応する.

\section{EXAFS の応用例}

\section{1 物性への応用}

放射光が水平方向に高度に偏光している†ことを 用い れば単結晶試料や配向性の良い多結晶試料の異方性を調 べることができる，理論の節で述べたように EXAFS の 一般的な表式には電場ベクトル $\vec{\varepsilon}$ が入っている.

$$
\begin{aligned}
\sum \chi_{\alpha i}(k)= & 3 \sum_{i}\left(\overrightarrow{r_{i}} \cdot \vec{\varepsilon}\right)^{2} \frac{N_{\alpha i}}{k r_{\alpha i}{ }^{2}} f_{i}(k, \pi) \\
& \times \exp \left(-\gamma_{i} r_{\alpha i}\right) \times \sin \left(2 k r_{\alpha i}+\phi_{\alpha i}\right) \\
& \times \exp \left(-\sigma_{i}{ }^{2} k^{2}\right)
\end{aligned}
$$

ここで $\left(r_{i} \cdot \varepsilon_{l}\right)=\cos \theta_{i}$ とかくと有効配位数 $N_{\alpha i} *$ は実際 の配位数 $N_{\alpha i}{ }^{\prime}$ と次の関係にある††.

$$
N_{\alpha i} *=3 \sum_{j} \cos ^{2} \theta_{i} N_{\alpha i}
$$

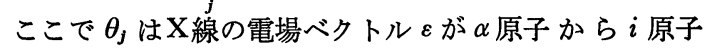
に対する方向ベクトルとのなす角である. 電場べクトル と単結晶あるいは固体表面となす角度をかえることによ って原子配列の異方性を調べることができる. 図36に

\footnotetext{
†放射光自体は約 $86 \%$ の偏光度であるが結晶反射による Lorentzpolarization の結果 $93 \%$ にまで高められている.

$+\dagger \theta$ について $2 \pi$ の積分を行うと $N_{\alpha i} *=N_{\alpha i}$ となる. 配向のない粉
} 末試料ではこれに相当する。 


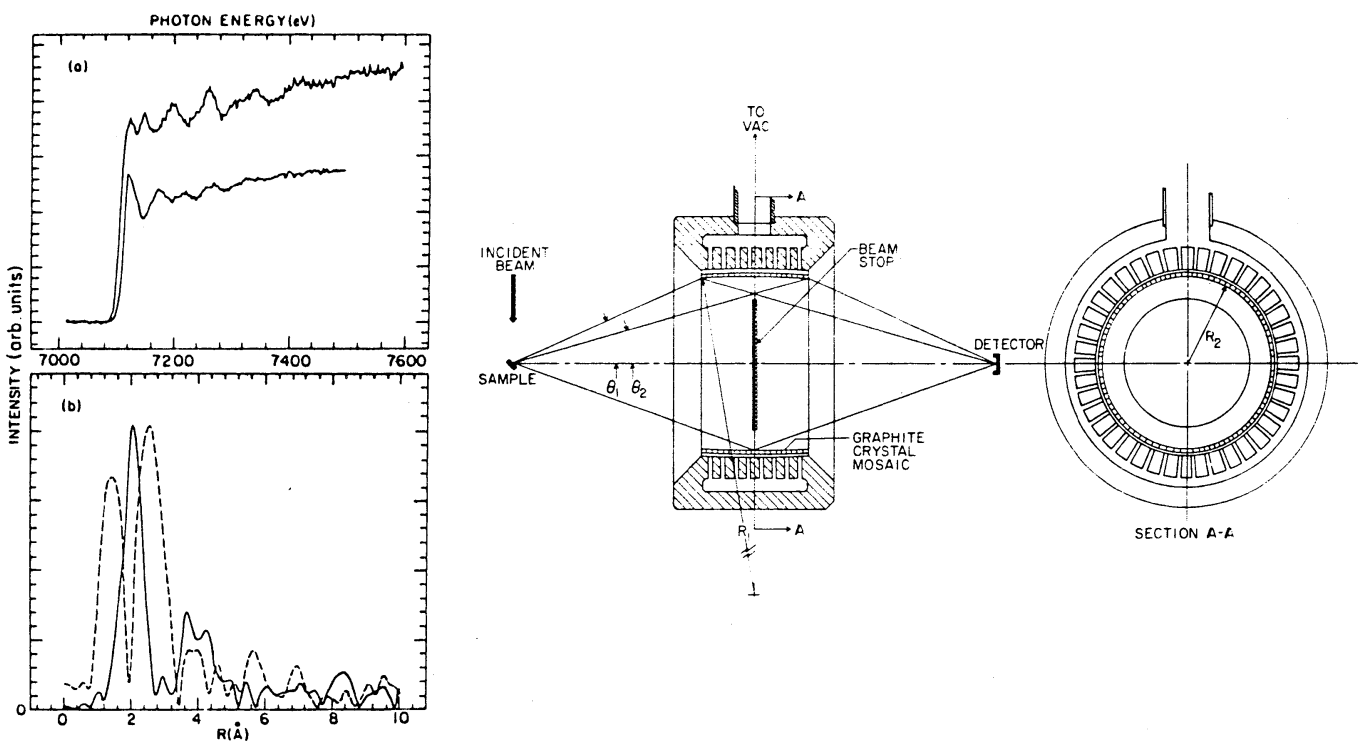

図37 蛍光 EXAFS 実験装置(右)とそれを用いた測定データ(左)

異方性の大きな $\mathrm{Zn}$ 金属単結晶について G. Brown 達が 行った偏光依存性の実験 ${ }^{36)}$ を示した。図中(a)は $\mathrm{a}$ 軸, (b) は $\mathrm{c}$ 軸方向に電場ベクトルを平行にして測定した 金属 $\mathrm{Zn}$ の Zn K EXAFS である. $\chi(k)$ に大きな変化がみ られる. (c)にフーリェ変換の結果を示した. 実線, 点線 は各々 $\mathrm{a}$ 軸, $\mathrm{c}$ 軸に電場ベクトルが平行な場合に対応す る.この結果は $\mathrm{Zn}$ 金属の結晶構造の異方性によって良 く説明できる. 偏光依存性を用いれば表面に吸着された 原子の配向性を調べることもできる37).

3.1 で述べたように極微量含まれる原子の蛍光 EXAF $\mathrm{S}$ を測定するには $S / N$ 比よく広い立体角にわたって蛍 光 X線を集めることが重要である. 通常蛍光 $\mathrm{X}$ 線以外に 励起 $\mathrm{X}$ 線の弾性・非弹性散乱等のバックグラウンドが同 時に測定される. 試料と検出器の間にモノクロメーター を置くことによって信号である蛍光X線のみを検出する ことができる ${ }^{18,19)}$. 図37にそのような系での測定例 ${ }^{187}$ 示した。試料は $\mathrm{Cu}$ 中に $75 \mathrm{ppm}$ 含まれる $\mathrm{Fe}$ で(a)は還 元状態（上）および酸化状態（下）の Fe K EXAFS ス ペクトル，(b)は還元状態（実線）打よび酸化状態(点線) のフーリェ変換の結果である. この結果から $\mathrm{Cu}$ 中で, $\mathrm{Fe}$ 原子は単純な $\mathrm{FeO}, \mathrm{Fe}_{2} \mathrm{O}_{3}, \mathrm{Fe}_{3} \mathrm{O}_{4}$ のよらな酸化物と して存在するのではなく, $\mathrm{Cu}, \mathrm{Fe}, \mathrm{O}$ 原子からなる複 雑なクラスターをつくっていることが推量された. この 他蛍光 EXAFS はへモグロビンやチトクロームC な ど の生体物質への応用もさかんでさる.

EXAFS の非晶質物質の構造研究への応用に関しては すでに解説 ${ }^{32,38,38)}$ がでており, 詳しくはそれらを参照さ れたい，長距離秩序を有しない非晶質や液体ではX線回
折による構造解析法は使えない，散乱強度 $I(k)$ をフー リエ変換して得られる動径分布関数の多成分系への適用 には困難な点が多く EXAFS の応用も多成分系に対する ものが多い. 非晶体では原子分布は広がっているため, 一般には結晶のような Gauss 分布を仮定することはで きない. 非晶質における原子分布は単体の場合, 2 体分 布関数 $g_{i j}(r)$ によって記述される. $g_{i j}(r)$ は $i$ 原子から $r$ だけ離れたところの $j$ 原子の原子密度を平均密度 $\rho_{0}$ で規格化したもので, 弾性散乱の強度 $I(k)$ と次の関係 にある。

$$
\begin{aligned}
I(k)= & \left\langle f^{2}\right\rangle+\sum_{i}^{n} \sum_{j}^{n} \bar{C}_{i} \bar{C}_{j} f_{i} f_{j}^{*} \frac{1}{k} \int_{0}^{\infty} 4 \pi r \rho_{0} \\
& \times\left[g_{j}(r)-1\right] \sin k r \mathrm{~d} r \\
\left\langle f^{2}\right\rangle & =\sum_{i}^{n} f_{i} f_{i}^{*}=\sum_{i}^{n} \bar{C}_{i}\left|f_{i}\right|^{2}
\end{aligned}
$$

ただし $k=4 \pi \sin \theta / \lambda$

ここで $\bar{C}_{i}, \bar{C}_{j}$ は $i, j$ 成分の原子濃度, $f_{i}, f_{j}$ は原子散乱 因子である. ここで部分構造因子 $S_{i j}(k)$ を次式によっ て定義する.

$$
S_{i j}(k)=1+\frac{1}{k} \int_{0}^{\infty} 4 \pi r \rho_{0}\left[g_{i j}(r)-1\right] \sin k r \mathrm{~d} r
$$

これにより $I(k)$ は部分構造因子の和としてあらわす。

$$
\begin{aligned}
& I(k)=\left\langle f^{2}\right\rangle-\langle f\rangle^{2}+\langle f\rangle^{2} S(k) \\
& \langle f\rangle^{2}=\left(\sum_{i}^{n} \bar{C}_{i} f_{i}\right)^{2}=\sum_{i}^{n} \sum_{j}^{n} \bar{C}_{i} \bar{C}_{j} f_{i} f_{j}^{*} \\
& S(k)=\sum_{i}^{n} \sum_{i}^{n} \frac{\bar{C}_{i} \bar{C}_{j} f_{i} f_{j}^{*}}{\langle f\rangle^{2}} S_{i j}(k)=\sum_{i}^{n} \sum_{i}^{n} W_{i j} S_{i j}, \\
& W_{i j}=\frac{\bar{C}_{i} \bar{C}_{j} f_{i} f_{j}^{*}}{\langle f\rangle^{2}}
\end{aligned}
$$



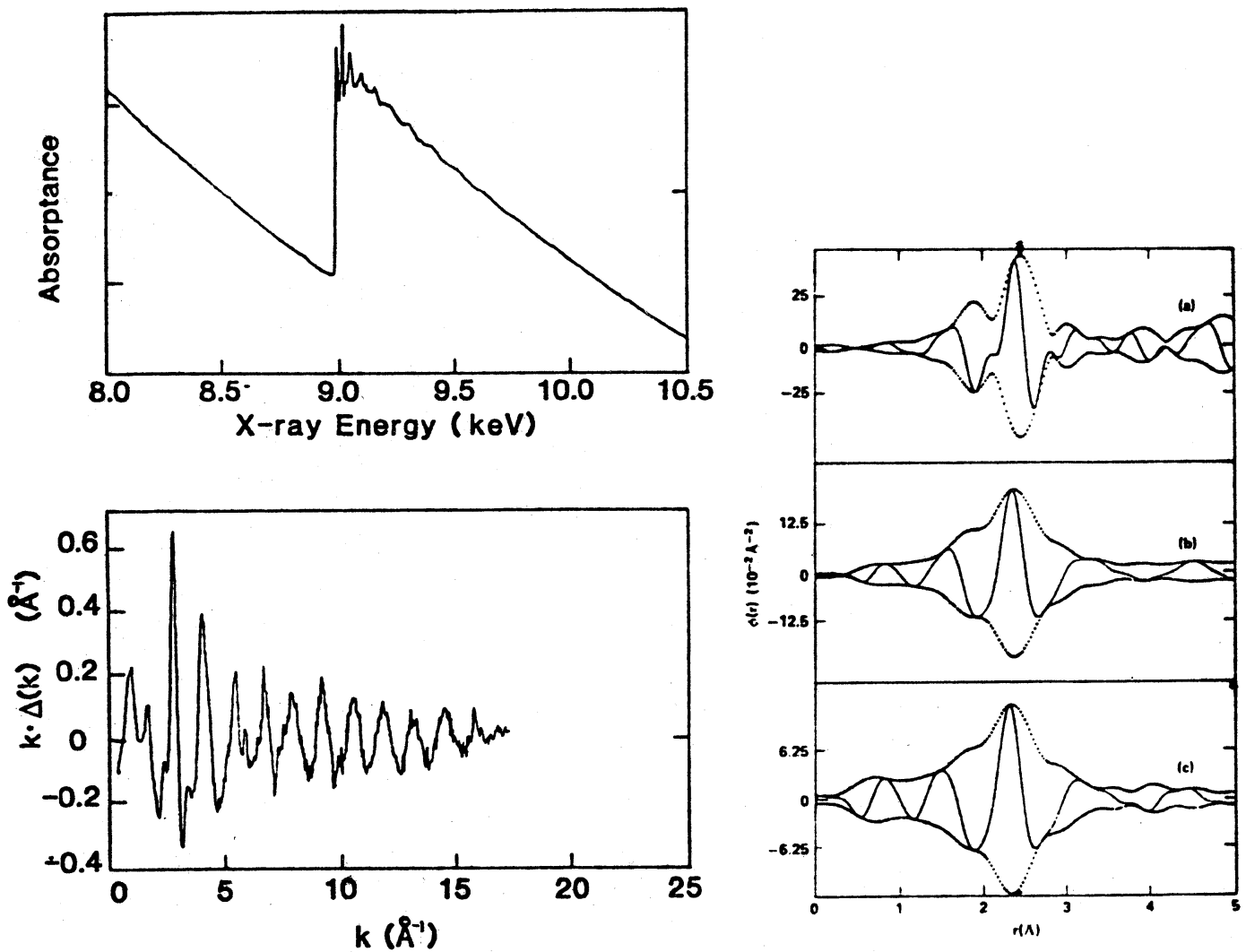

図38 超イオン伝導体 CuI の EXAFS (左) とフーリエ変換の温度変化(右)

したがって $S_{i j}(k)$ が何らかの形で 分離できればフーリ エ変換によって原理的には部分動径関数を得ることが可 能である. 左辺は実験によって得られる量であるので, 右辺の $S_{i j}(k)$ の係数 $W_{i j}$ を $\mathrm{n}$ 成分系に対しては少な くとも ${ }_{n+1} C_{2}$ 個変えた組をつくりこれらを連立して解け ば $S_{i j}(k)$ が得られる． $W_{i j}$ を変えるには，(1)組 成すな わち $\bar{C}_{i}, \bar{C}_{j}$ を変化させる ${ }^{40)}$ か, (2)異常分散*を利用して

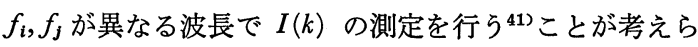
れる.

しかし(1)は $S_{i j}$ が組成に依存する場合は使えないし(2) では異常分散項の変化は小さいので, 連立方程式を解く 時の誤差が大きい．また成分原子の種類が増えるととも に連立方程式の数が急激に増加するためその適用は現実 にはせいぜい 2 成分が限界である，これに対して EXA FS では吸収原子のまわりの原子分布を独立に調べるこ とができる点で有利である. しかし $k$ の小さい領域の情 報が不足しているため $r$ の離れた所の原子相関は失われ $ろ^{35)}$.

結晶では調和振動子の範囲で熱振動が等方的であるた

*) $f_{i}$ は異常分散項を含めれば一般に複素数である. $f_{i}(k)=f_{0 i}(k)+f_{i}{ }^{\prime}(k)+i f_{i}{ }^{\prime \prime}(k)$
め Gauss 分布で近似して Debye-Wallor 因子により原 子位置のゆらぎの大きさをあらわした. これに対して非 調和振動や非晶質を取り扱らためには，2 体分布関数を 用いる必要があるが ${ }^{35)}$ ，単なるフーリエ変換によっては 動径分布は得られない. T. Hayes はモデル化合物の原 子分布を再現するようなピーク関数をフーリェ変換後に コンボリュートし実験データを再現する原子分布を求め る方法を提案した ${ }^{32)}$.

図38に超イオン伝導体である CuI の(a)77 K, (b)573K, (c)743Kに抒ける Cu K-EXAFS のフーリェ変換の結果 を示した. 1.4 3.2Aにかけてのピークは $\mathrm{Cu}$ イオンの まわりの 4 個の I イオンによるもので解析の結果, 高温 で(1)原子分布は非対称に広がり (2)ピークは内側にシフト することがわかった，これまでのモデル42,43)ではこれら の結果は説明できないことから J.B. Boyce は新しいモ デルをたてた. 彼らは $\mathrm{Cu}$ イオンは低温で 4 配位サイト に落ち着いているが高温相ではよりエネルギーの高い 6 配位サイトを占めるようになりサイト間の移動がイオン 伝導に寄与すると考えている，最近我々は銅イオン導電 性固体電解質 $\mathrm{Rb}_{4} \mathrm{Cu}_{16} \mathrm{I}_{7} \mathrm{Cl}_{13}$ の $\mathrm{Cu} \mathrm{K}$ 吸収 スペクトル の温度依存性を測定した. この結果, $\mathrm{Cu}$ I 等の超イオ 


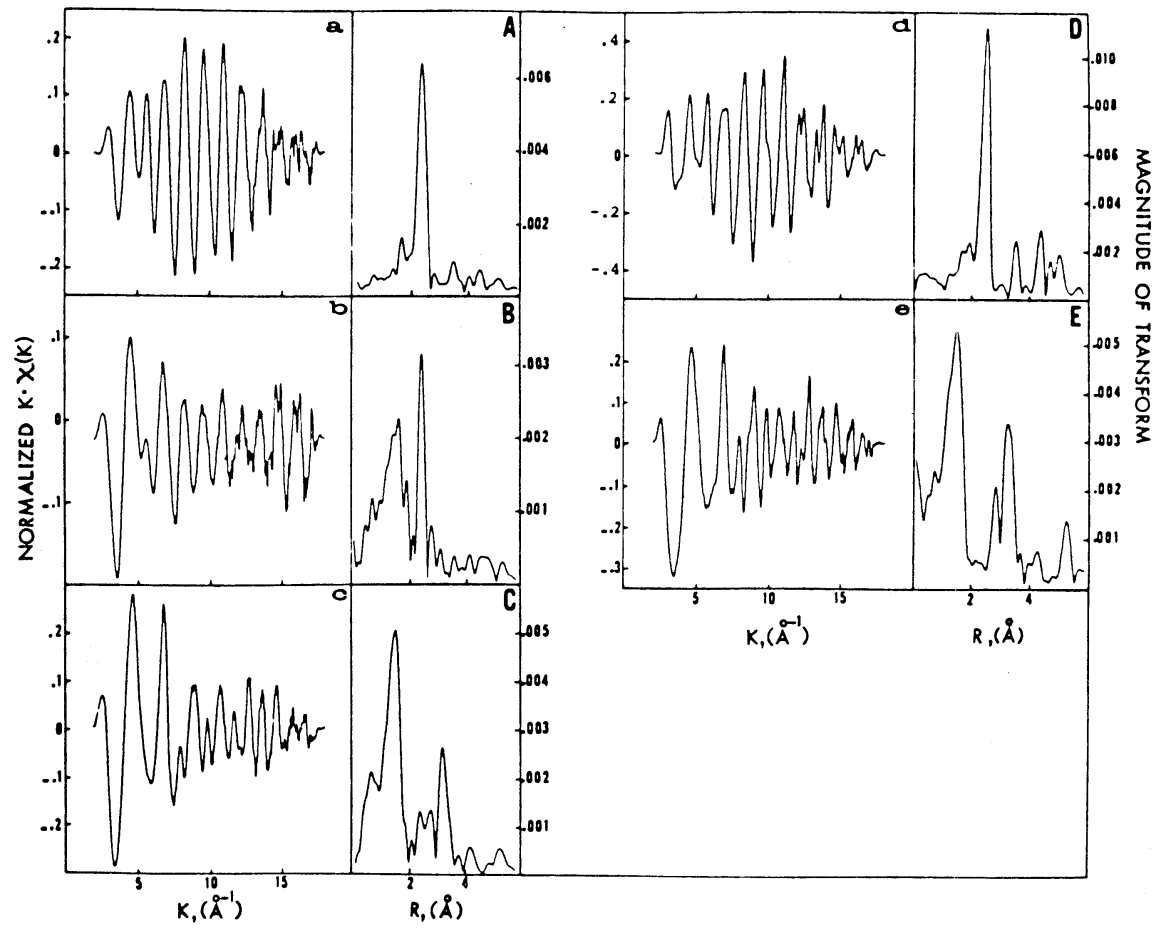

図39 $\mathrm{SiO}_{2}$ 上の $\mathrm{Ru}$ 金属の $\mathrm{Ru} \mathrm{L}$ EXAFS スペクトルおよびフーリェ変換

a 還元状態, $\quad$ b $25^{\circ} \mathrm{C} 7.6 \mathrm{mmO}_{2}$ 需囲気においた状態, $\quad$ c : $400^{\circ} \mathrm{C}$ で $\mathrm{O}_{2}$ 中加熱, $\quad \mathrm{d}: \mathrm{Ru}$ 金属,

e $\mathrm{RuO}_{2}$

ン伝導体に比べて $\mathrm{Cu}$ のまわりの原子動径分布の温度変 化ははるかに小さいことがわかった。

\section{2 化学への応用}

化学反応では触媒が反応機構において中心的役割を果 たしていることが少くない，触媒機構を明らかにするた めには赤外吸収, ラマン分光, ESR, NMR や光電子, オージェスペクトル等の分光学的手法が組み合わされて いる. しかしいずれも直接的な構造解析手段ではなく触 媒活性に深い関連のある中心金属の配位については不明 な点が多かった. EXAFS の特長を生かして担持触媒へ の応用が数多く報告されている. 将来は測定の高速化に ともない中間生成物の構造やキネティクスへの応用も期 待されている. 触媒の構造は電子状態と深いつながりを 持っため XANES を並用することが行われている ${ }^{45)}$.

図39(a)は $\mathrm{SiO}_{2}$ 上の担持触媒である $\mathrm{Ru}$ 金属 $(1 \%)$ を $\mathrm{H}_{2}$ で還元した後測定した Ru L EXAFS，図のAは そのフーリエ変換の結果でさる. また図の $\mathrm{b}$ は $25^{\circ} \mathrm{C}$ で $7.6 \mathrm{~mm}$ の $\mathrm{O}_{2}$ 雾囲気にさらした状態, c $1400^{\circ} \mathrm{C}$ の $\mathrm{O}_{2}$ 中に置いた状態のスペクトルである. d, e は比較のた め示した $\mathrm{Ru}$ 金属, $\mathrm{RuO}_{2}$ のスペクトルでこれらはデー 夕解析の際のモデル化合物として用いられた。

$\mathrm{a}(\mathrm{A}) \mathrm{d}(\mathrm{D})$ の比較から $\mathrm{SiO}_{2}$ 上の還元状態にある $\mathrm{Ru}$ 触
媒は $\mathrm{Ru}$ 金属と同じ結合を持っていることがわかる，a は $\mathrm{d}$ に比べて $\chi(k)$ の振幅が小さい理由は微粒子であ るため表面付近の原子が多いことによると思われる.

$7.6 \mathrm{~mm} \mathrm{O} \mathrm{O}_{2}$ にさらした状態でも $\mathrm{Ru}-\mathrm{O}$ 結合とみられる ピークがあらわれているが，Ru-Ru 結合がかなり存在 している. 酸素中で $400^{\circ} \mathrm{C}$ に加熱することによって完全 な酸化が起こり $\mathrm{Ru}-\mathrm{Ru}$ 結合はなくなるのがわかる。こ の例では酸化の過程を追らために in-situ で測定された ものである. このような構造変化を示す系に対して直接 原子配列を迅速に調べることができることは EXAFS法 の有利な点である.

EXAFS は溶液にも適用できるためイオンの溶媒和を 調べることができる.これまでに $\mathrm{CuBr}_{2}$ の濃い水溶液 では $\mathrm{Cu}$ イオンのまわりに $\mathrm{Br}$ 原子が配位していること が EXAFS によって確められている Werner 達が $\mathrm{KMnO}_{4}$ の水溶液について行った実験 ${ }^{47)}$ 紹介する.

図40上段に固体の $\mathrm{KMnO}_{4}$ 抢よび水溶液（0.4モル／ l)の Mn K EXAFS スペクトルである. K吸収端直前 の鋭いピークは $\mathrm{MnO}_{4}^{-}$イオンの離散的な分子軌道への 遷移によるもので， $6,600 \mathrm{eV}$ までの領域で水溶液と 固 体で大きく異なるのはこの領域 (XANES) が，電子状 


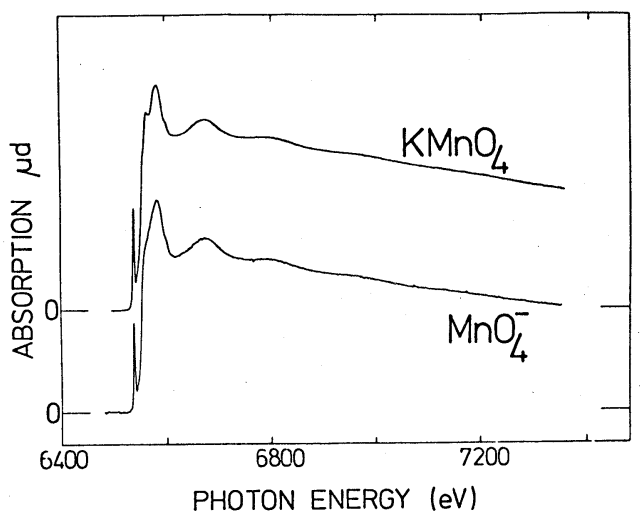

$\chi(k)$

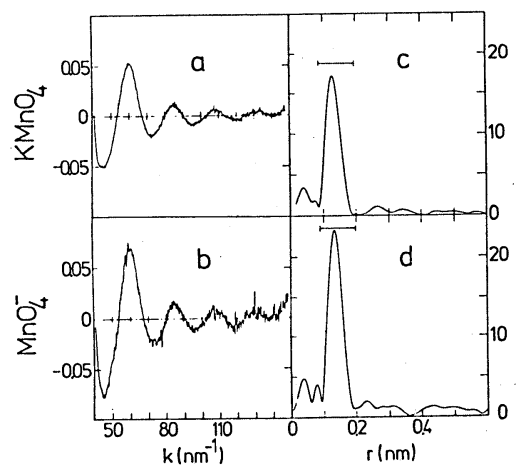

図40 $\mathrm{KMnO}_{4}$ 固体および水溶液の $\mathrm{MnK}$ 吸収ス ペクトル

態や多体効果等の固体効果を反映しているためである.

下段には規格化された EXAFS とそのフーリエ変 換を 示した. 溶液状態で $\mathrm{Mn}$ 原子は $1.649 \AA$ はなれた所にあ る 4 個の酸素原子に配位しており，らねり（beating）を 利用したさらに詳しい解析の結果, $1.634 \AA$ 離れたとこ ろに 3 個の酸素原子, $1.759 \AA$ 離れたところに 1 個 の酸 素が存在することがわかった。このように吸収原子のま わりに互に接近した 2 つの結合距離を持つ原子が存在す るときはそれらの間の干渉効果によりフーリエ変換の絶 対值のピーク位置, 強度は実際の原子位置, 配位数と対

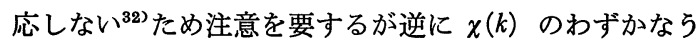
ねり (beating) を利用することによってわずかな結合距 離の差を調べることができる ${ }^{47,48)}$.

\section{3 生物への応用}

生体物質では活性中心が，特異的な生理機能に関係し ており,これらの機能を理解する上で, 中心金属原子の 配位を研究することが重要な課題の一つである.

生物分野は, 生体試料の単結晶構造解析が難かしいこ ともあって, EXAFS による研究が最も期待されている 分野である.これは(1)生体物質の単結晶づくりの困 難 さ，(2)分子量が大きいため，構造解析が複雑となり局所
的な原子配置を問題とする場合は誤差が大きくなるこ と, (3)数千点といらブラッグ反射を集めるのに時間がか かるため放射損傷が起こるなどの理由による. さらに 「生きている」状態すなわち溶液の状態で生体物質に起 こる様々な現象を調べるという基本的な要請の上からも EXAFS が有利である. ヘモグロビンはへム蛋白の一つ であり分子量64,000中に 4 個の $\mathrm{Fe}$ 原子が存在する. 各 々原子は, ポルフィリン環中の 4 個の $\mathrm{N}$ 原子の面内に存 在し, も51個の $\mathrm{N}$ 原子が $\mathrm{Fe}$ 原子に配位して 4 個のポ ルフィリン環をつないでいる，酸素分子の $\mathrm{Fe}$ 原子への 配位しやすさは他のポルフィン環の Fe 原子がすでに酸 素分子に配位しているかどらかに影響されることが知ら れている. 酸素分子の配位によって構造が変化するかど らか, またどのよらにして一方のポルフィリン環中の $\mathrm{Fe}$ 原子に配位した酸素分子の存在が他のポルフィリン環の Fe 原子に作用するかが重要な問題 であった. Perutz 達 は，酸化型では面内にある $\mathrm{Fe}$ 原子が還元型では面内か らはずれるためにN原子との結合を介してポルフィリン 環の $\mathrm{Fe}$ 原子同士が相互作用するといら仮説 ${ }^{49,50)}$ をたて た.これに対して Eisenberger 達はへモグロビンとその モデル化合物の酸化型および環元型について EXAFS を蛍光法によって 測定した ${ }^{51,52)}$. 図41にへモグロビン (Hb) およびモデル化合物 $(\mathrm{PF})$ の酸化型および還 元 型に対する Fe K EXAFS を示した. これからへモグロ ビンと PF は酸化型と還元型で構造が異なることがわか る. さらに詳しい解析の結果, ヘモグロビンの還元型で は面内からのずれは0.2Aで Perutz 達の值よりもかなり 小さい.

図42に，バクテリアフェレドキシンの(a)単量体，(b) 2 量体, (c) 3 量体のモデルおよび EXAFS スペクトルと そのフーリエ変換の結果 ${ }^{53}$ を示した. フーリエ変換の最 も大きなピークは $\mathrm{Fe}$ 原子のまわりの $\mathrm{S}$ 原子によるもの で，(b)，(c)ではこれより遠い所に Fe 原子によるピーク が存在しているがこれを利用すれば単量体， 2 量体，3 量体を区別することができる．単量体では $\chi(k)$ の振動 は，最近接の $\mathrm{S}$ 原子のみによるので， $\mathrm{S}$ 原子の後方散乱 振幅のプロファイルを振幅に反映した単純な振動となっ ているのに対して，2 量体以上では他に处側の $\mathrm{Fe}$ 原子 による寄与があるため $\chi(k)$ は複雑ならねりを生じてい る.

このようならねりを生じさせる構造パラメーターは必 ずしも一意的には定まらないが，構造モデルがいくつか ある場合にはそれらを区別するのに役立つ.

図42中点線は構造モデルの実施值（実線）に対するカ

*) 放射線照射によってできた電子が水分子に付加し $\mathrm{H}_{2} \mathrm{O}$ - となった ४०. 


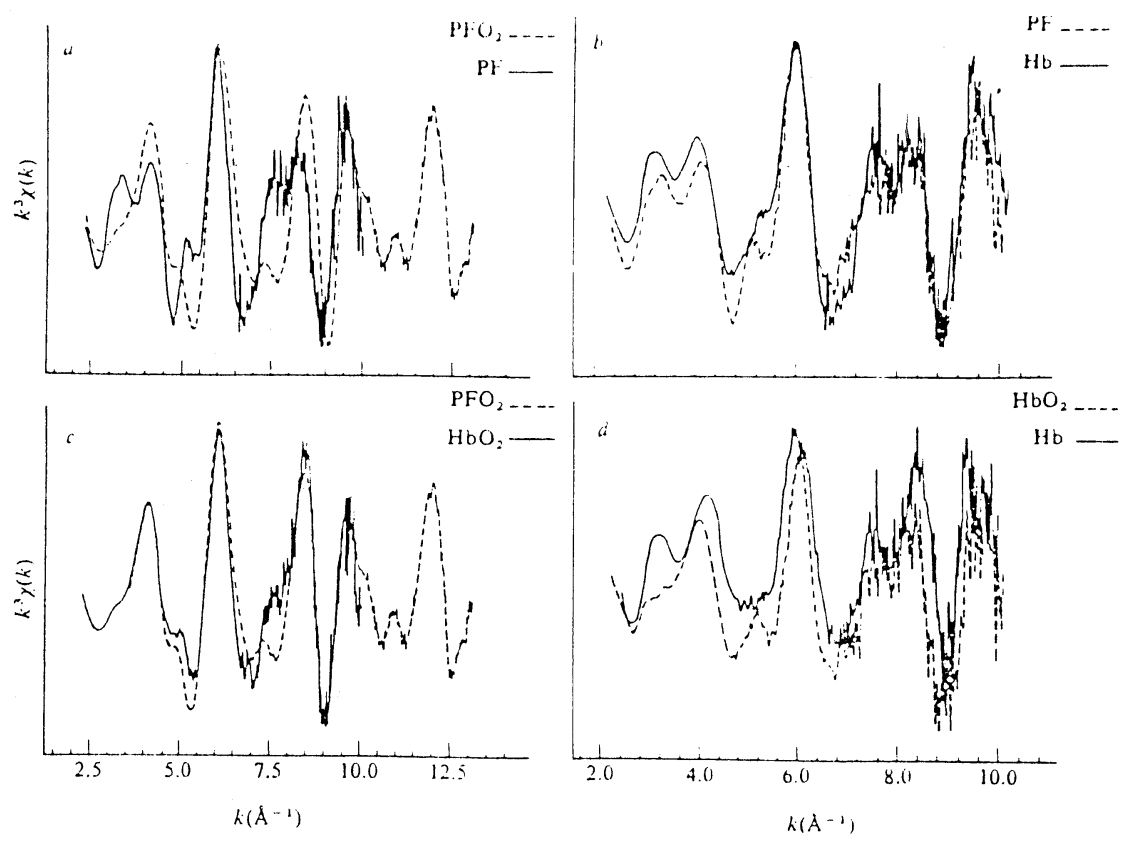

図41 ヘモグロビン $(\mathrm{Hb})$ およびモデル化合物 (PF) の Fe K EXAFS

(a)
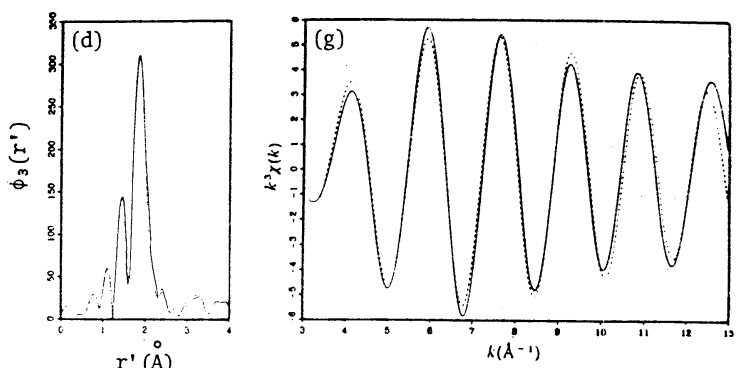

(b)
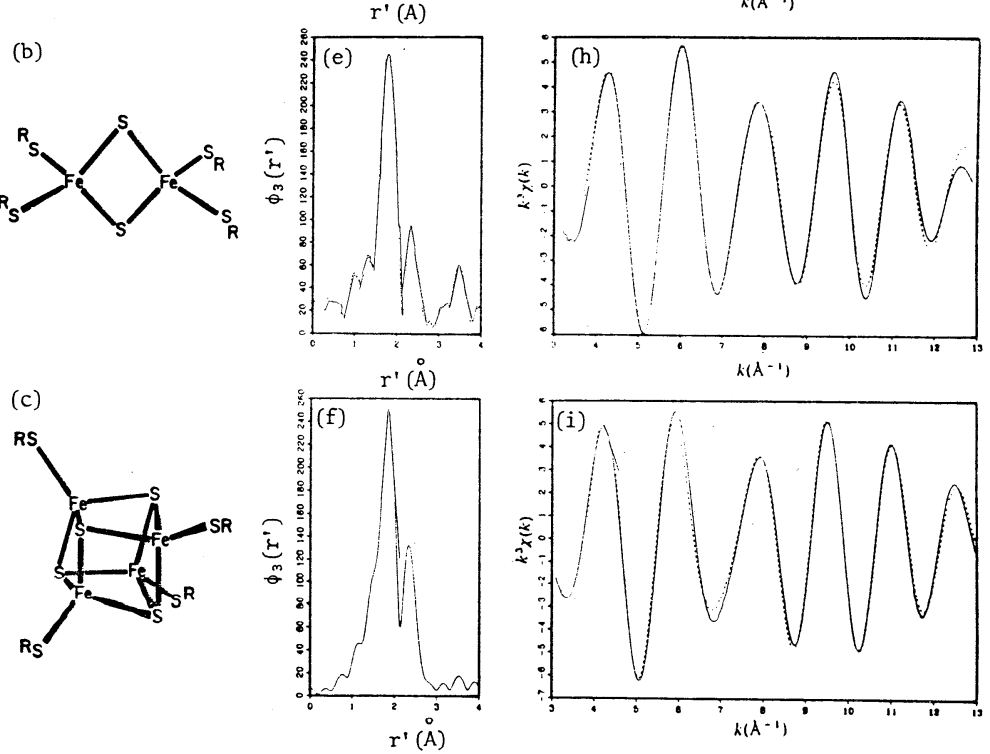

図42 バクテリアフェレドキシンモデル化合物の構造と Fe K EXAFS 
ーブフイットの結果を示している. 生物物質に対する $\mathrm{E}$ $\mathrm{XAFS}$ 実験で重要な問題は放射損傷である. 放射光の 長時間照射による効果として(1)試料の放射損傷および(2) 水和電子*による酸化がある. 分光学的手段あるいは生 体反応により放射損傷の効果をモニターすることが望を しい. 液体窒素温度付近で移動度が小さくなるために低 温で測定することで水和電子の影響を減らすことができ るる ${ }^{54)}$.

\section{4 固体表面への応用}

実験法の項でも述べたように，表面構造を調べる方法 としてこれまで良く用いられてきたのは，二次電子収量 を測定する方法と，オージェ電子収量を測定する方法の 2つである. 前者は, J.Stöhr を中心とした SSRLのグ ループがグラスホッパー型分光器を用いて行なってきて いる. これまで, 表面酸化した $\mathrm{Ni}$ や $\mathrm{Al}$ の表面構造, $\mathrm{Si}$ (111) 面上に吸着した $\mathrm{O}, \mathrm{GaAs}(110)$ 面上の $\mathrm{O}, \mathrm{Al}$ (111) 面上に単分子層以下で吸着した $\mathrm{O}$ 等の系の表 面 構 造が調べられている，最初は単にO と基質の結合距離を 求めるだけであったが，最近では，放射光の偏光性を利 用することによって，O原子の配位の仕方まで推定する ことができるようになっている.

一方，後者の方法では，Citrin らの Bell 研のグルー プが硬X線領域で実験を行っている55)。これらは, $\mathrm{Ag}(111)$ 上の I の配位, $\mathrm{Cu}(111)$ 上の I の配位, $\mathrm{Cu}$ (111)，(110)上での $\mathrm{Te}$ の配位の仕方の違い等の研究で ある.

また，最近 SSRL では， $800 \mathrm{eV} \sim 4.5 \mathrm{keV}$ のエネル

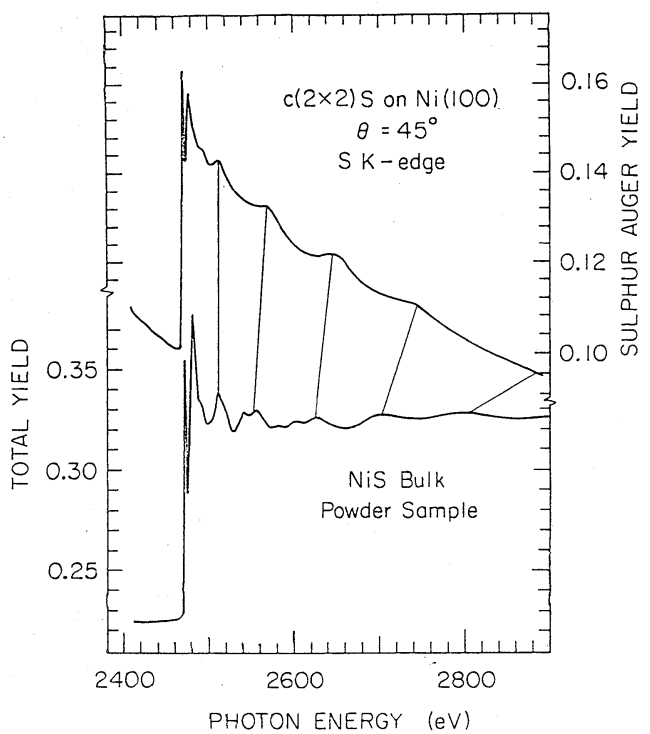

図43 $c(2 \times 2) \mathrm{S} / \mathrm{Ni}(100)$ 及び, バルク NiS のEXAFS スペクトル

ギー領域をカバーする軟 $\mathrm{X}$ 線二結晶分光器 Jumbo が実 用化されるようになり，軟X線領域に吸収をもつ元素の 系についての EXAFS・SEXAFS が活発に行われるよ らになった. ここでは, その中の一例として, $\mathrm{Ni}(100)$ 面上に $\mathrm{c}(2 \times 2)$ で吸着した $\mathrm{S}$ の配位を決定した, Brennan らの実験 ${ }^{29}$ を紹介する.

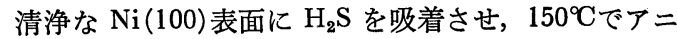
ールすると，安定な $\mathrm{c}(2 \times 2) \mathrm{S}$ の LEED パターンが

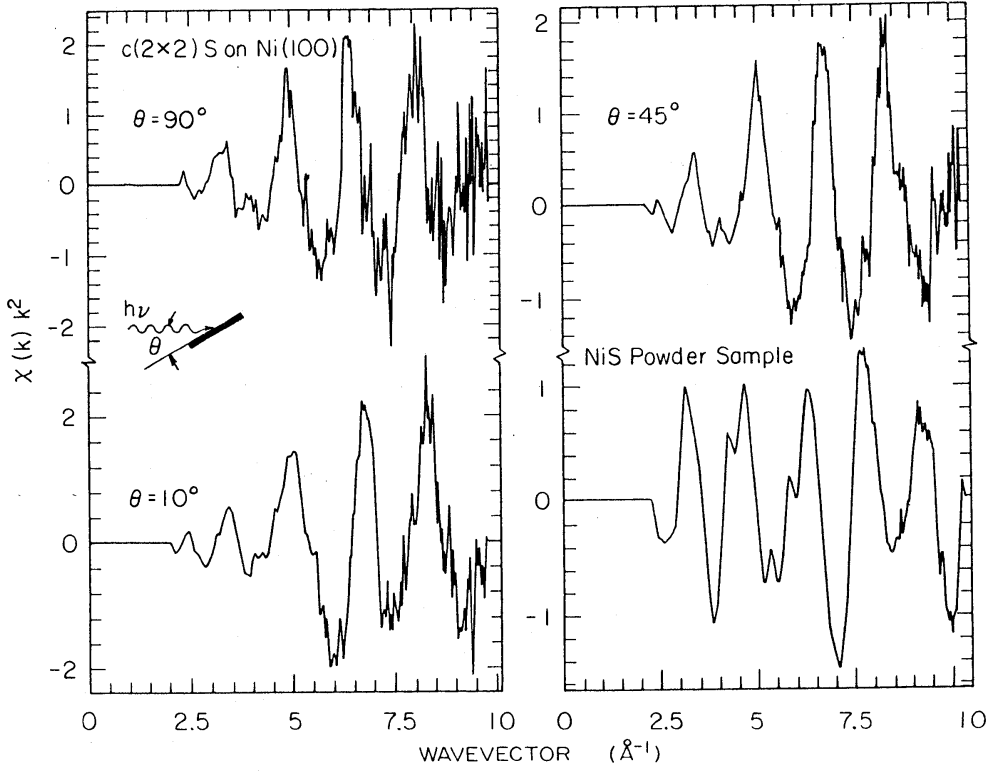

図44 $c(2 \times 2) \mathrm{S} / \mathrm{Ni}(100)$ 表面及び，バルク $\mathrm{NiS}$ 試料の EXAFS 振動部分 


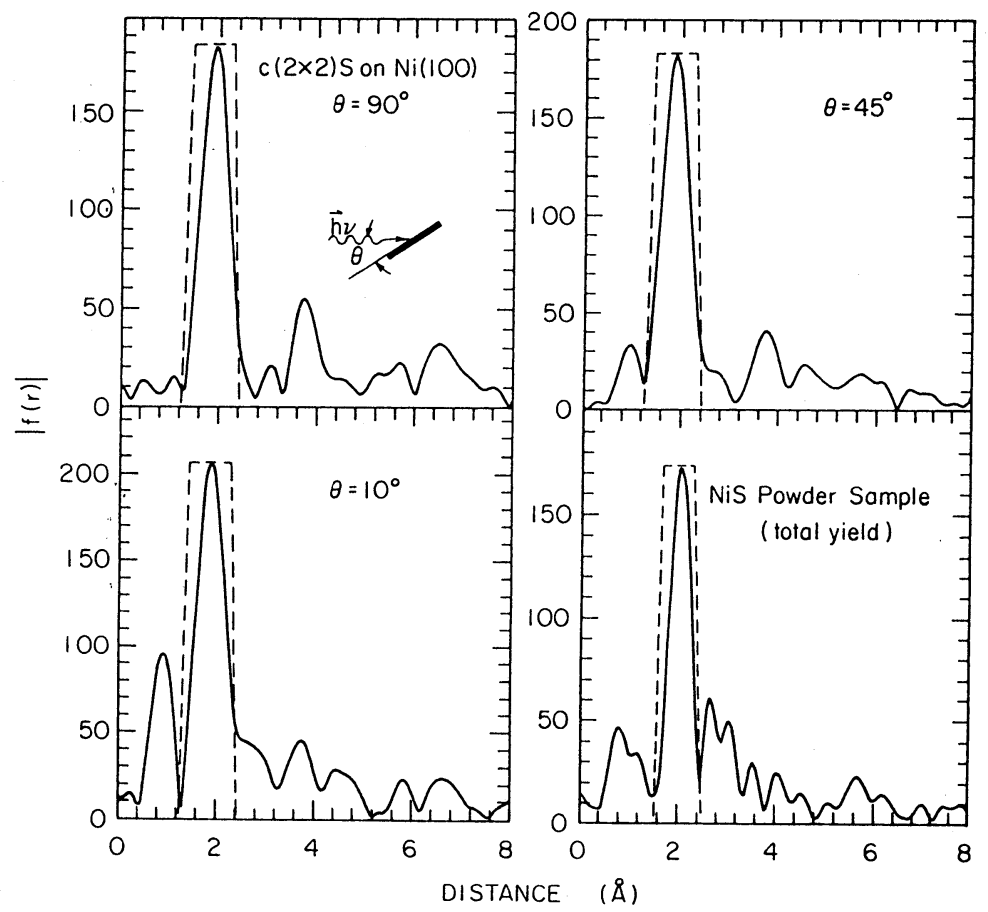

図45 $k$ 空間から $\mathrm{R}$ 空間へのフー リエ変換

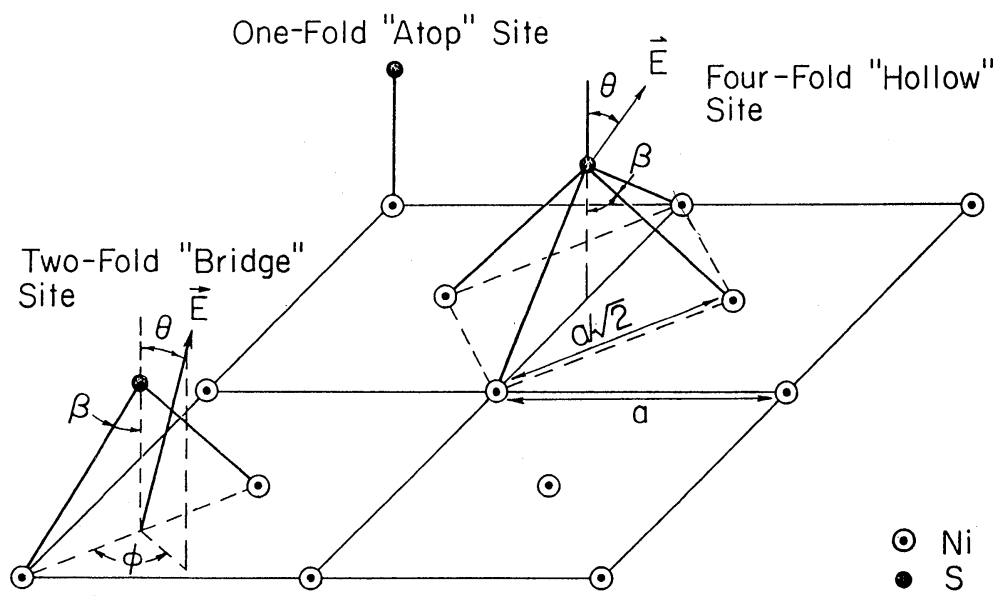

図46 Ni(100) 面上での 3 種 類の可能な吸着サイト

得られる.これを試料として, $\mathrm{Ge}(111)$ 結晶による分光 で, $\mathrm{S}$ のK吸収端 $(2472 \mathrm{eV})$ から約 $450 \mathrm{eV}$ までの $\mathrm{E}$ $\mathrm{XAFS}$ スペクトルを得ることができる.これは，図23 に示したようにオージェ電子収量法による測定の方が, $S / N$ 比も $S / B$ 比も良い. $\mathrm{c}(2 \times 2) \mathrm{S} / \mathrm{Ni}(100)$ のスペ クトルを $\mathrm{NiS}$ 粉末のスペクトルと比較して図43 に示し た. $\mathrm{S}$ 吸着系の方が振動の同期が短いことは明らかであ り, これから, 表面に吸着した $\mathrm{S}$ と基質の $\mathrm{Ni}$ との結合 距離がバルクの Ni-S 距離に比べて短いことが定性的に 結論できる.これは EXAFS の一つの大きな特長であ る. 試料対する入射角 $\theta$ を $90^{\circ}, 45^{\circ}, 10^{\circ}$ に変えて S
EXAFS を測定し，この振動部分をとり出したのが図44 であり，これらのフーリエ変換の結果が図45である. $\mathrm{NiS}$ の Ni-S 結合距離は2.39Aであることがわかってい るので，位相シフトを同じと仮定すれば吸着 $\mathrm{S}$ と $\mathrm{Ni}$ と の距離を求めることができる. 得られた結果は $2.23 \AA \pm$ $0.02 \AA$ であり, バルクより約 $0.16 \AA$ 短くなっている.

更に, 図44の点線で囲んだ, S-Ni に起因するピーク だけを抽出し，フーリエ逆変換すると単一の正弦波曲線 が得られる筈である. この振幅の $k$ 依存性 は式(7)に示 したようになる。 ここで，異なる入射角でのスペクトル の振幅の比をとると, 次式のように, 殆どのパラメータ 
表 $1 c(2 \times 2) \mathrm{S} / \mathrm{Ni}(100)$ の配位数とその比

\begin{tabular}{|c|c|c|c|c|}
\hline \multirow{2}{*}{ 入射角 } & \multirow{2}{*}{ 実験值 } & & 論 & 值 \\
\hline & & (a) Hollow 型 & (b) Bridge 型 & (c) Atop 型 \\
\hline $10 * / 45 *$ & $1.16 \pm 0.10$ & 1.20 & 4.31 & $\infty$ \\
\hline $10^{*} / 90 *$ & $1.15 \pm 0.10$ & 1.09 & 1.59 & 1.94 \\
\hline $10 *$ & $4.42 \pm 1.04^{a}$ & 4.49 & 4.03 & 2.91 \\
\hline $45 *$ & $3.77 \pm 0.79^{a}$ & 4.13 & 2.53 & 1.50 \\
\hline $90 *$ & $3.94 \pm 0.75^{\mathrm{a}}$ & 3.75 & 0.94 & 0 \\
\hline
\end{tabular}

は消えて単に有効配位数 $N *$ の比となる†.

$$
A_{i}\left(\theta_{1}\right) / A_{i}\left(\theta_{2}\right)=N_{i}^{*}\left(\theta_{1}\right) / N_{i}^{*}\left(\theta_{2}\right)
$$

有効配位数は式(48)で表わしたように，結合の方向と 電場ベクトルの方向のなす角に依存しているから，入射 角 $\theta$ の関数となる. S が $\mathrm{Ni}(100)$ 面上に吸着する場 合 の配位の仕方として，図46に示したよ5に，@四原子の 間に挟まる hollow 型配位，®二原子の橋かけをする bridge 型配位, (C一原子の直上に吸着する atop 型配位 の 3 種類が考えられる，それぞれについて $N_{i}{ }^{*}$ は次式の ように表わされる.

(a) $N_{i}^{*}=12 \cos ^{2} \beta \cos ^{2} \theta+6 \sin ^{2} \beta \sin ^{2} \theta$

(及び゙○

$$
N_{i}{ }^{*}=6 \cos ^{2} \beta \cos ^{2} \theta+6 \sin ^{2} \beta \sin ^{2} \theta \cos ^{2} \phi
$$

結合距離は既に求めてあるので，それぞれの入射角につ いて上式から $N_{i}^{*}$ を求めると，表 1 のよらになる，実験 值との比較から@の hollow 型が妥当な配位と結論でき よ5.な扮， $N_{\imath}{ }^{*}$ の絶対值は $\mathrm{NiS} の N_{l}=6$ として, $\mathrm{NiS}$ との比から求めたものでさる.

\section{6. まとめ一将来の動向}

これまで述べて来たように，EXAFS はその実験法も 解析法もほぼ確立し, 局所構造解析手段として定着して きた感がある．言い換えれば，どんな試料でも測定すれ ば即論文になる，いわゆる青年期は終わり，壮年期，熟 年期に向かおうとしていると言えよう。これからの $\mathrm{EX}$ $\mathrm{AFS}$ の向からべき方向がどらなるか，未熟な我々筆者 には推測が困難であるが，当面考えられる動向として次 のような事が考えられよう。

(1)理論面では，X線吸収端近傍の解釈が今後の課題と なろう。これには，多体効果を考慮した，高い励起状態

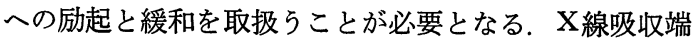
近傍のスペクトル，XANES は原子の配向の角度を敏感 に反映しているので，局所構造のより詳細な情報を得る ことができる. (EXAFS では,この部分をすてている訳 であり，実に勿体ない話である.)

\footnotetext{
†（48)式参照のこと.
}

(2実験面では，構造の時間変化の追跡，いわゆるダイ ナミック EXAFS が今後の課題として興味樑い，ここ でもとりあげたエネルギー分散型の EXAFS は,数ミリ 秒の測定時間を可能にしたが，これは，透過型の実験し かできない，表面構造のダイナミックスを調べる方法の 開発が残されている.

(3) いろいろな検出手段を併用した EXAFS，即ち， 透過, 蛍光X線, オージェ電子, 二次電子, 光脱離イオ ン等の検出手段で EXAFS を測定することにより, バル クと表面の構造の違いをより鮮明に描き出すことができ よ5.

(4)放射光の指向性を利用して, 試料の局所分析と, 局 所的な構造解析を行らこと. これは工業面での需要が多 い事が予想される. 今年からフォトンファクトリーで共 同利用実験が始まっている. 本稿が少しでも放射光を利 用してこれから EXAFS 実験を行うとしている人々の 役に立てれば筆者らの幸とするところである.

\section{[文献〕}

1) R. de L. Kronig: Z. Phys. 70 (1931) 317.

2) D. E. Sayers, E. A. Stern and F. W. Lytle: Phys. Rev. Lett. 27 (1971) 1204.

3) C. A. Ashley and S. Doniach: Phys. Rev. B11 (1975) 1279.

4) P. A. Lee and J. B. Pendry: Phys. Rev. B 11 (1975) 2795.

5) E. A. Stern: Phys. Rev. B10 (1974) 3027.

6) B. K. Teo and P. A. Lee: J. Am. Chem. Soc. 101 (1979) 2815.

7) J. Stöhr: SSRL Report 80/07 (1980).

8) P. A. Lee and G. Beni: Phys. Rev. B15 (1977) 2862.

9) P. J. Durham, J. B. Pendry and C. H. Hodges: Solid State Comm. 38 (1981) 159.

10) G. Beni and P. M. Platzman: Phys. Rev. B14 (1976) 1514.

11) J. Rehr, E. A. Stern, R. L. Martin and E. R. Davidson: Phys. Rev. B17 (1978) 560.

12) T. A. Carlson: Photoelectron and Auger Spectroscopy, Plenum, New York, (1975). 
13) E. A. Stern, B. A. Bunker and S. M. Heald: Phys. Rev. B21 (1980) 5521.

14) A. Liebsch: Phys. Rev. B13 (1976) 544.

15) M. L. Knotek and P. J. Feibelman: Phys. Rev. Lett. 40 (1978) 964.

16) S. Hunter: SSRP Report 77/04 (1977) 38.

17) J. Jaklevic, J. A. Kirby, M. P. Klein, A. S. Robertson, G. S. Brown and P. Eisenberger: Solid State Comm. 23 (1977) 679.

18) J. B. Hastings, P. Eisenberger, B. Lengeler and M. L. Perlman: Phys. Rev. Lett. 43 (1979) 1807.

19) M. Marcus, L. S. Powers, A. R. Storm, B. M. Kincaid and B. Chunce: Rev. Sci. Instrum. 51 (1980) 1023.

20) E. A. Stern and S. M. Heald: Rev. Sci. Instrum. 50 (1979) 1579.

21) S. P. Crumer and R. A. Scot: Rev. Sci. Instrum. 52 (1981) 395.

22) T. Matsushita and R. P. Phizackerley: Jpn. J. Appl. Phys. 20 (1981) 2223.

23) R. P. Phizackerley, Z. U. Rek, G. B. Stephenson, S. D. Conradson, K. O. Hodgson, T. Matsushita and H. Oyanagi: Submitted to J. Appl. Cryst.

24) S. Khalid, R. Emrich, R. Dujari, J. Shultz and J. R. Katzer: Rev. Sci. Instrum. 53 (1982) 22.

25) J. Stöhr, V. Rehn, I. Lindau and R. Z. Bachrach: Nucl. Instrum. and Meth. 152 (1978) 43.

26) J. Cerino, J. Stöhr, N. Hower and R. Z. Bachrach: ibid 172 (1980) 227.

27) J. Stöhr, L. Johansson, I. Lindau and P. Pianetta: Phys. Rev. B20 (1979) 664.

28) Z. Hussain, E. Umbach, D. A. Shirley, J. Stöhr and J. Feldhaus: to be published in Nucl. Instrum. and Methods.

29) S. M. Brennan: SSRL Report 82/03 p. 27.

30) Intern. Tubles for X-ray Cryst. Vol. IV, Kynech Press, Eng (1974).

31) 市田浩三・吉本富士市 : スプライン関数とそ の応用 教育出版 (1973)

32) T. M. Hayes: J. Non Cryst. Solids 31 (1978) 57.

33) H. Oyanagi, K. Tsuji, S. Hosoya, S. Minomura and T. Fukamachi: J. Non-Cryst. Solids 35, 36 (1980) 555.

34) P. Eisenberger and B. Lengeler: Phys. Rev. B 22 (1980) 3551.

35) P. Eisenberger and G. S. Brown: Solid State Comm. 29 (1979) 481.

36) G. S. Brown, P. Eisenberger and P. Schmidt: Solid State Comm. 24 (1977) 201.

37) P. A. Lee: Phys. Rev. B 13 (1976) 5261.

38) P. A. Lee, P. H. Citrin, P. Eisenberger and B. M. Kincaid: Rev. of Mod. Phys. 53 (1981)
769.

39）大柳宏之，細谷資明：日本結晶学会誌22(1980) 57

40) Y. Waseda: The Strueture of Non Cryst. Matterials, Liquids and Amorphous Solids, McGrawHill, New York (1980).

41) Y. Waseda and S. Tamaki: Phil. Mag. 32 (1975) 951.

42) S. Miyake, S. Hoshino, T. Takenaka: J. Phys. Soc. Japan 7 (1952) 19.

43) T. Matsubara: J. Phys. Soc. Japan 38 (1975) 1076.

44) F. W. Lytle: Ann. Rev. Phys. Chem. 30 (1979) 215.

45) F. W. Lytle, P. S. P. Wei, R. B. Greegor, G. H. Via and J. H. Sinfelt: J. Chem. Phys. 70 (1979) 4849.

46) A. Fontaine, P. Lagarde, D. Raoux, M. P. Fontana, G. Maisano, P. Migliardo and F. Wanderlingh: Phys. Rev. Lett. 41 (1978) 504.

47) P. Rabe, G. Tolkiehn and A. Werner: J. Phys. C 12 (1979) 899.

48) G. Martens, P. Rabe, N. Schwentner and A. Werner: Phys. Rev. Lett. 39 (1979) 1411.

49) M. F. Perutz: Nature 228 (1970) 726.

50) J. L. Hoard: Science, 174 (1971) 1295.

51) P. M. Eisenberger, R. G. Shulman, G. S. Brown and S. Ogawu: Proc. Natl. Acad. Sci. USA 7, 3 (1976) 491.

52) P. M. Eisenberger, R. G. Shulmun, B. M. Kincaid, G. S. Brown and S. Ogawa: Nature 274 (1978) 30.

53) R. G. Shulman, P. Eisenberger, B. K. Teo, B. M. Kincaid and G. S. Brown: J. Mol. Biol. 124 (1978) 305.

54) B. Chance, W. Pennie, M. Carman, V. Legallais and L. Powers: to be published in Anal. Chem. 122 (1982).

55) P. H. Citrin, P. Eisenberger and R. C. Hewitt: Phys. Rev. Lett. 41 (1978) 309.

\section{EXAFS に関する解説・総説リスト}

\section{英文のむの}

1) E. A. Stern, J. Vac. Sci. Technol., 14, (1977) 461.

2) R. G. Shulman, P. Eisenberger and B. M. Kincaid: Ann. Rev. Biophys. Bioeng. 7 (1978) 559.

3) E. A. Stern: Contemp. Phys., 19, (1978) 289.

4) T. M. Hayes: J. Non-Cryst. Solids, 31 (1978) 57.

5) P. A. Lee: J. Phys. (Paris), Colloq., 39, C4, (1978) 120.

6) P. Eisenberger and B. M. Kincaid: Science, 200, (1978) 1441.

7) D. R. Sandstrom and F. W. Lytle: Ann. Rev. Phys. Chem., 30, (1979) 215. 
8) S. P. Cramer, K. O. Hodgson, Prog. Inorg. Chem., 25, (1979) 1.

9) B. K. Teo: Acc. Chem. Res., 13, (1980) 412.

10) P. A. Lee, P. H. Citrin, P. Eisenberger and B. M. Kincaid: Rev. Mod. Phys. 53 (1981) 769.

11) "Synchrotron Radiation Research" ed. by H. Winick and S. Doniach, Plenum Press (1980).

12) "EXAFS Spectroscopy, Techniques and Applications" ed. by B. K. Teo, Plenum Press (1981).

\section{和文のもの}

1) 細谷資明, 川村隆明, 深町共栄 : 応用物理 47 (1978) 708

2) 黒田晴雄, 藤川高志: 化学の領域33 (1979) 276.
3) 岩田深雪, 大柳宏之：化学と工業32 (1979) 298 .

4) 米沢富美子：日本物理学会誌，34 (1979) 589.

5) 川村隆明, 細谷資明 : 生物物理 19 (1979) 213

6) 飯塚哲太郎, 内多 契, 石村 巽, 大柳宏之: 生物物理19(1979) 223 .

7) 大柳宏之, 細谷資明 : 日本結 晶 学 会 誌 22, (1980) 57.

8）大柳宏之, 細谷資明 : 固体物理, 15, 7 (1980) 415.

9）大柳宏之, 太田俊明 : 表面科学 2, (1981)57.

10)物理学論文選集215: 川村隆明, 細谷資明編日 本物理学会

11）飯塚哲太郎：日本物理学会誌37 (1981) 455 .

12）太田俊明，日本金属学会誌 20 (1981) 570. 